\title{
The human occupation record of Gua Mo'o hono shelter, Towuti-Routa region of Southeastern Sulawesi
}

\author{
Sue 0'Connor, David Bulbeck, Philip J. Piper, Fadhila Aziz, \\ Ben Marwick, Fredeliza Campos, Jack Fenner, Ken Aplin, Fakhri, \\ Suryatman, Tim Maloney, Budianto Hakim and Rachel Wood
}

\begin{abstract}
Here we describe the excavation, chronology and assemblage from Gua Mo'o hono, a rockshelter in the Lake Towuti region in Southeast Sulawesi. The excavation produced glass, ceramics and pottery, dense faunal and lithic assemblages and a diversity of bone tools. The Gua Mo'o hono sequence demonstrates that humans were active in and around the rockshelter from at least $6500 \mathrm{cal} \mathrm{BP}$, and informs on early to late Holocene subsistence and technology in this region. Although the occupants of Gua Mo'o hono exploited a diverse range of fauna from a variety of habitats around the site, there appears to have been a particular focus on suids, both the babirusa and the Sulawesi warty pig.
\end{abstract}

Keywords: Gua Mo'o hono, Southeast Sulawesi, Holocene prehistory, pottery, stone artefacts, human remains, faunal remains, bone artefacts

\section{Introduction}

Excavation in caves and shelters in Sulawesi has largely been focused on the limestone karst region near Maros, which has a long history of investigation and has recently revealed some surprisingly early evidence for occupation as well as painted rock art dating back to the Pleistocene (Aubert et al. 2014). In 2012, we initiated a project to explore the Lake Towuti region in the southeastern arm of Sulawesi. As no previous research had been undertaken here, the project was designed with a broad brushstroke to encompass the human occupation record of this region from the Late Pleistocene to the Metal Age. During the course of the three-year project, five shelter and cave sites were tested with small excavations and new rock art was recorded in two of them (Bulbeck et al. 2016; Oktaviana et al. 2016). Three of the excavated sites were southeast of Lake Towuti near the small village of Walandawe: Gua Sambangoala, Gua Mo'o hono and Gua Talimbue (Figure 9.1). Here, we focus on the results of the excavation of Gua Mo'o hono, located about $90 \mathrm{~km}$ southeast of Lake Towuti. The excavation produced glass, ceramics and pottery, dense faunal and lithic assemblages and a diversity of bone tools. 


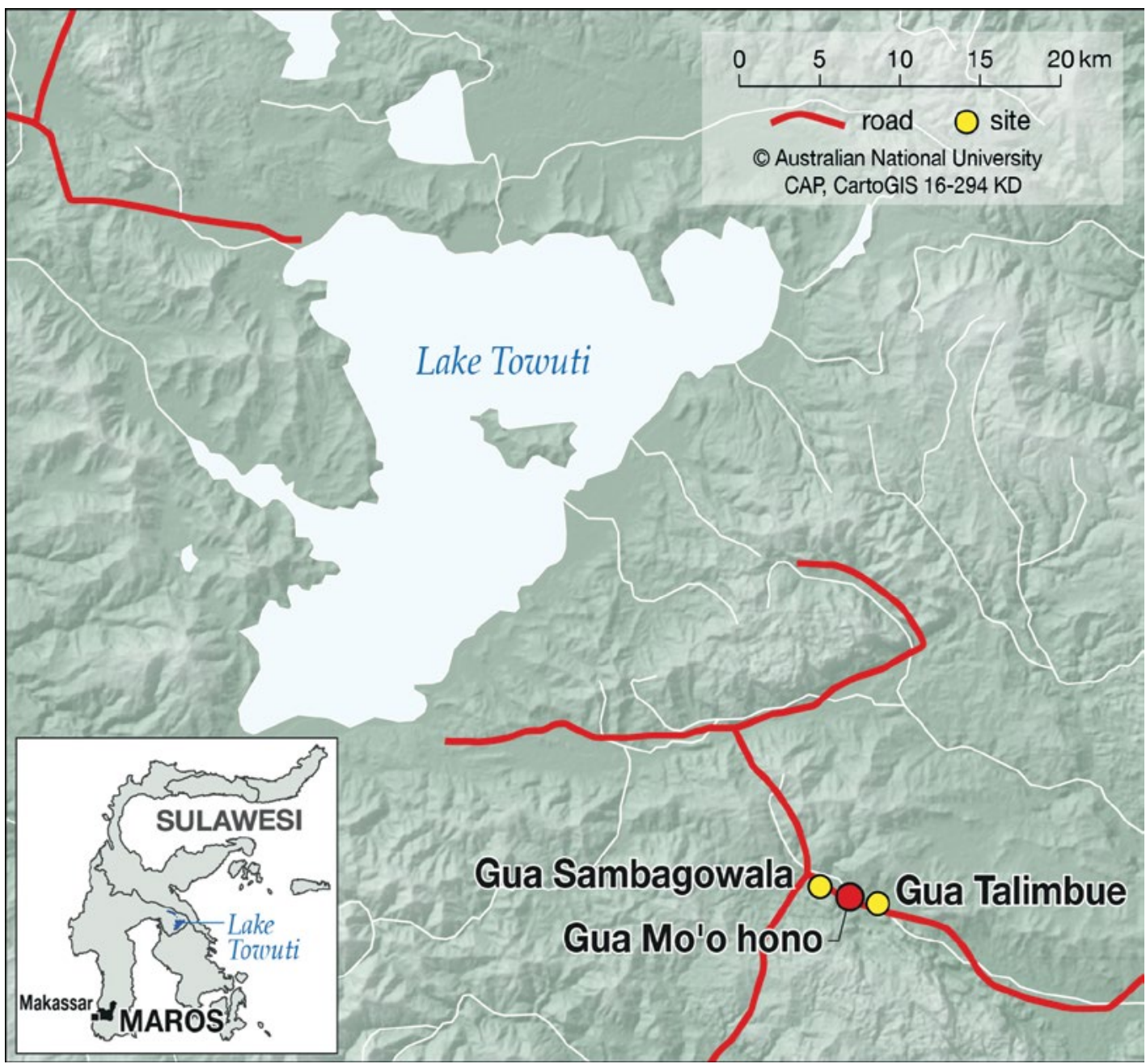

Figure 9.1: Map showing location of excavated sites in Walandawe area, and inset showing location of Lake Towuti and Maros region.

Source: CartoGIS, College of Asia and the Pacific, The Australian National University.

\section{Gua Mo'o hono excavation results}

\section{Site context and excavation methods}

Gua Mo'o hono is a limestone rockshelter in Desa (Village) Walandawe, Kecamatan (Subdistrict) Routa, Kabupaten (District) Konawe Utara at coordinates 3¹'40.0”S 12143'12.9”'E (Figure 9.1). It is located at the edge of the Sungai Wiwirano river flats approximately 344 metres above sea level (m asl) (Figure 9.2). The floor area of the shelter runs approximately $20 \mathrm{~m}$ from northwest to southeast and has a maximum width of up to c. $5 \mathrm{~m}$ from the back wall to the drip line (Figures 9.3 and 9.4). The excavation was carried out in the central area of the shelter where the floor was highest. Towards the southeast, the floor slopes at about $10^{\circ}$ to a slump zone where sediment is being actively eroded and lost through a fissure in the back wall into a deep cave below (Figure 9.4). 


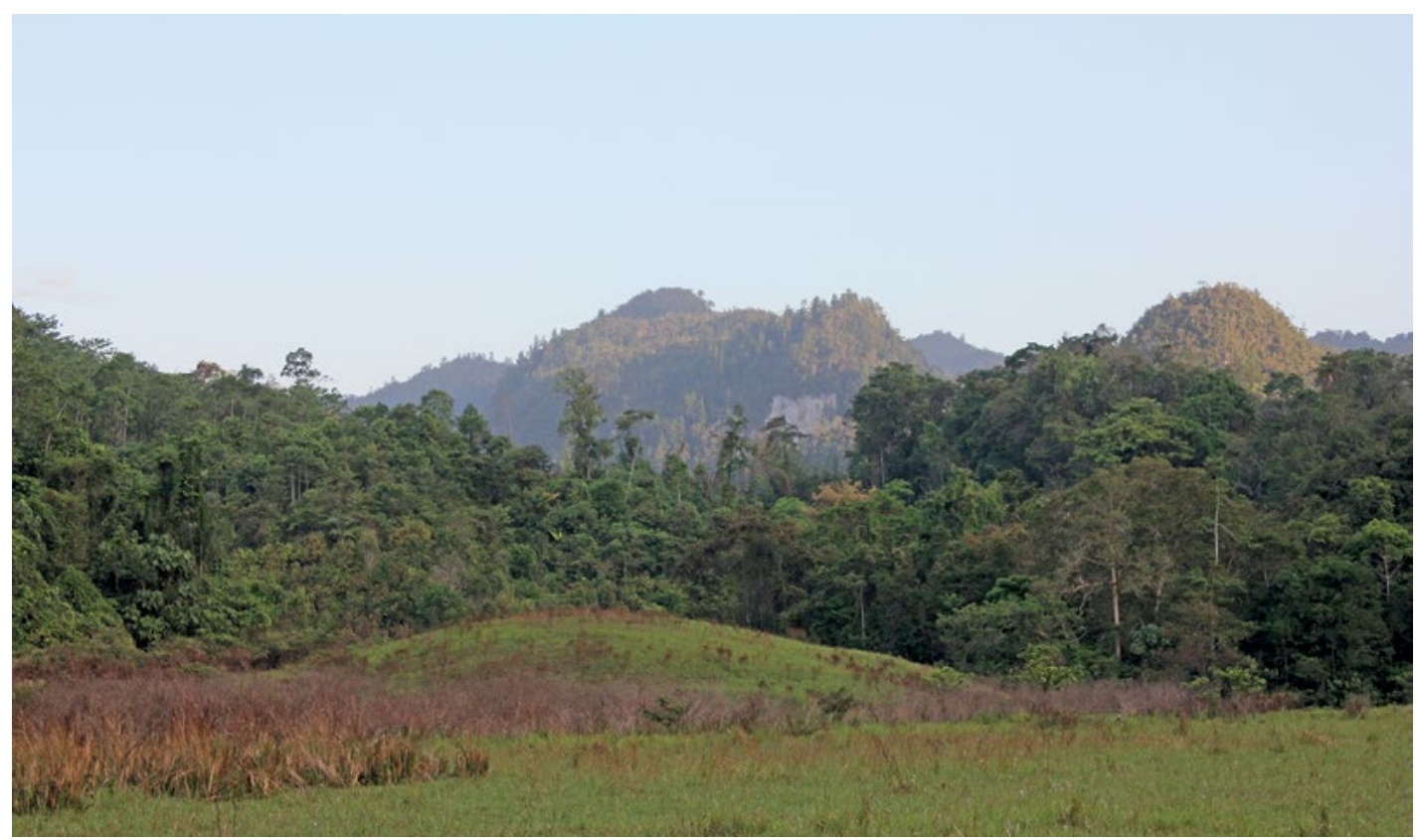

Figure 9.2: View of landscape on edge of the Sungai Wiwirano river flats.

Source: Photograph by Sue $0^{\prime}$ Connor.

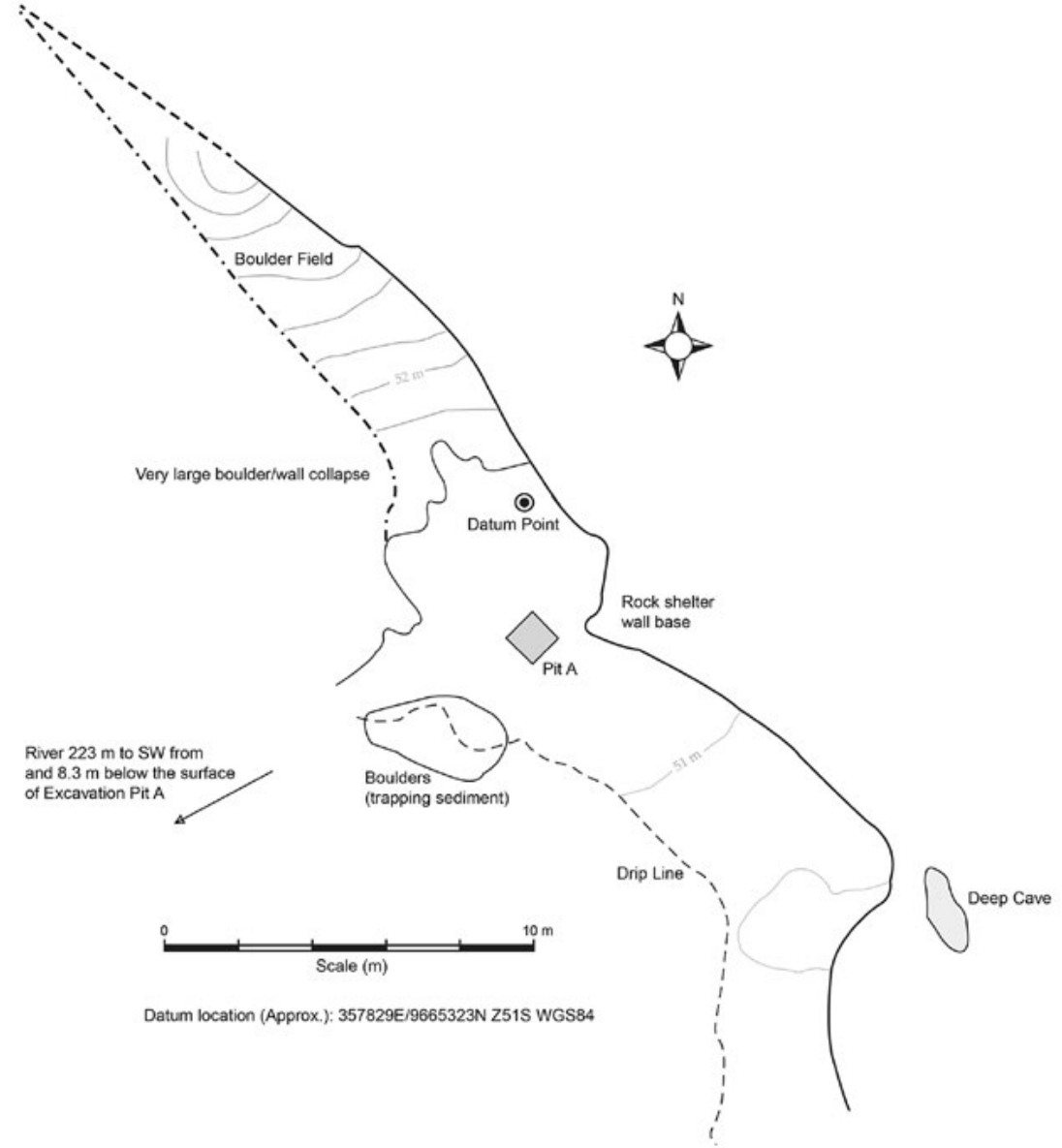

Figure 9.3: Plan of Gua Mo'o hono showing location of test pit and area of deep cavern. Source: Plan prepared by Jack Fenner. 


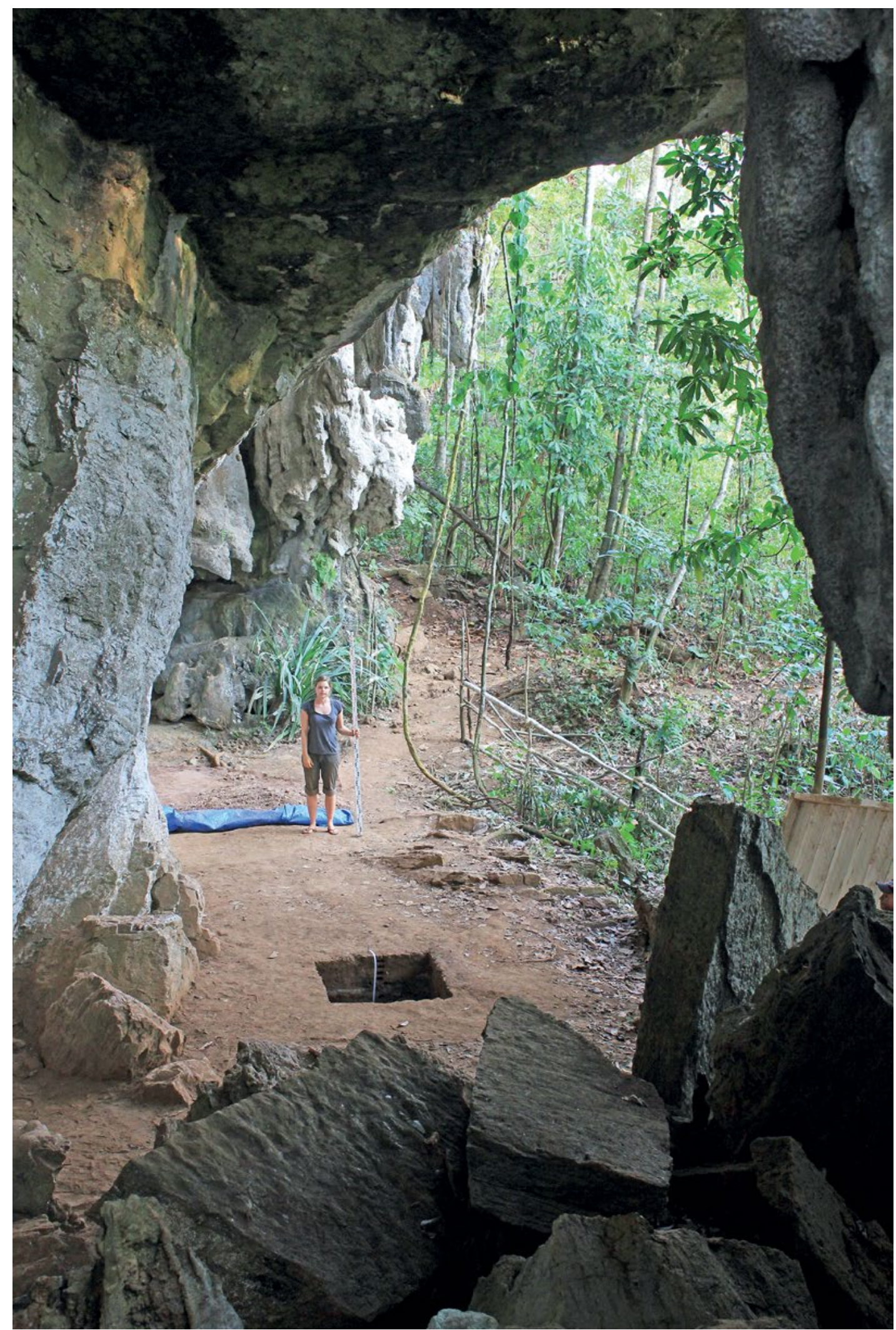

Figure 9.4: Gua Mo'o hono viewed from the northwest showing the location of the test pit and team member.

Source: Photograph by Sue o'connor. 


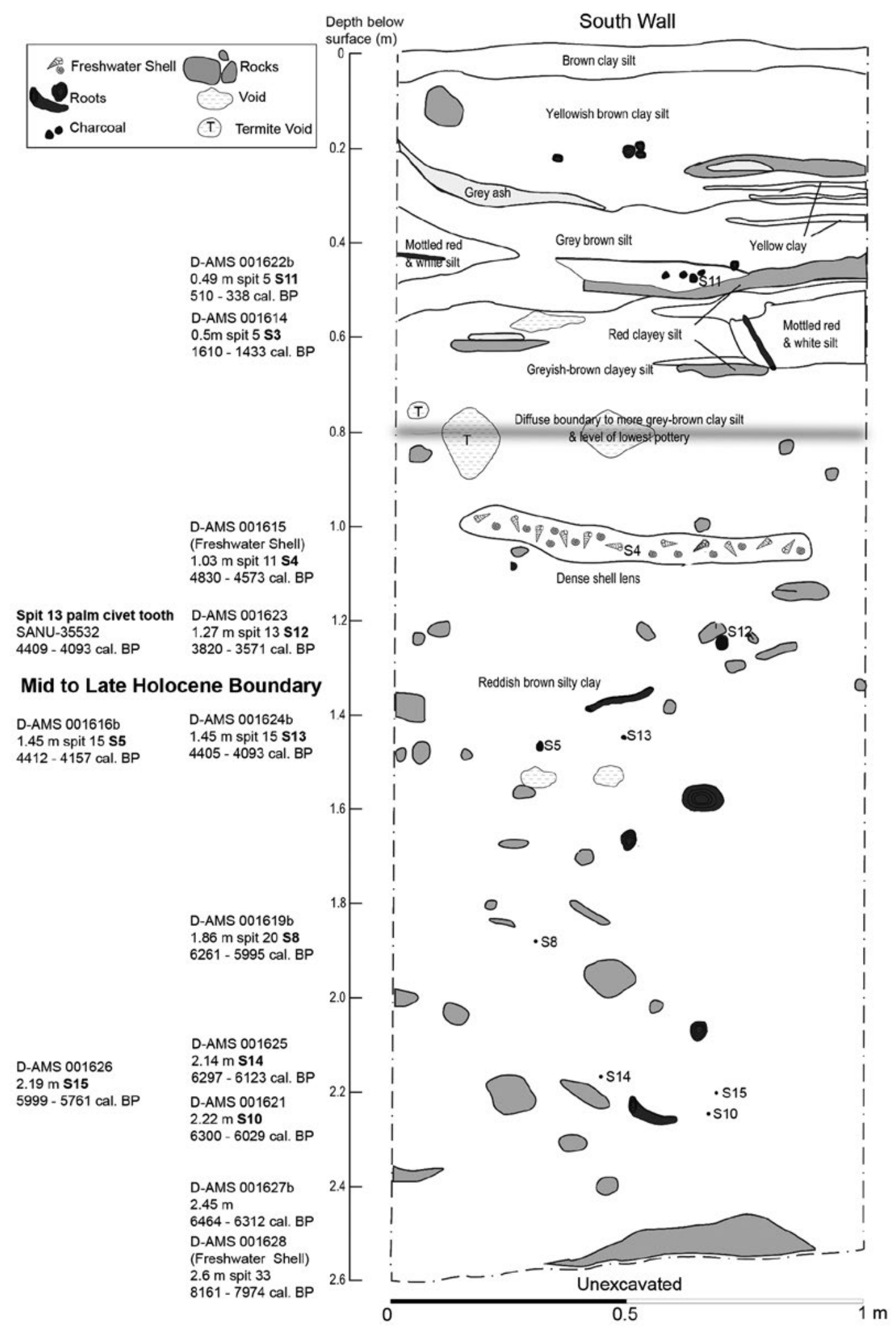

Figure 9.5: South section of Mo'o hono showing shell lenses, bioturbation features and location of dating samples.

Source: Section prepared by Ben Marwick. 
In October 2012, a single $1 \times 1 \mathrm{~m}^{2}$ test pit (Test Pit A) was excavated in 33 spits to a depth of about $2.7 \mathrm{~m}$ (Figures 9.5 and 9.6). Spits of approximately $10 \mathrm{~cm}$ were excavated in the upper $1.5 \mathrm{~m}$ (Spits 1-18) (Figure 9.5). Below this, spits were approximately $5 \mathrm{~cm}$ in depth. Figure 9.7 shows this reflected in the weight of total deposit excavated per spit, including finds, loose sediment and rock. The lowest spits were even smaller in terms of volume of sediment excavated owing to the large rocks encountered in plan that could not be removed. The upper metre of the deposit consisted of compact, well-sorted sandy silt with several distinct lenses of ash, charcoal and reddened sediment and abundant freshwater gastropods. Below these the deposit graded into increasingly clayey silt with an increase in weathered igneous rock and limestone cobbles. Excavation stopped when large limestone boulders filled the square at $270 \mathrm{~cm}$ depth (Spit 33). It seems likely that the archaeological deposit continues below this, but further investigation would require extension of the excavation area.

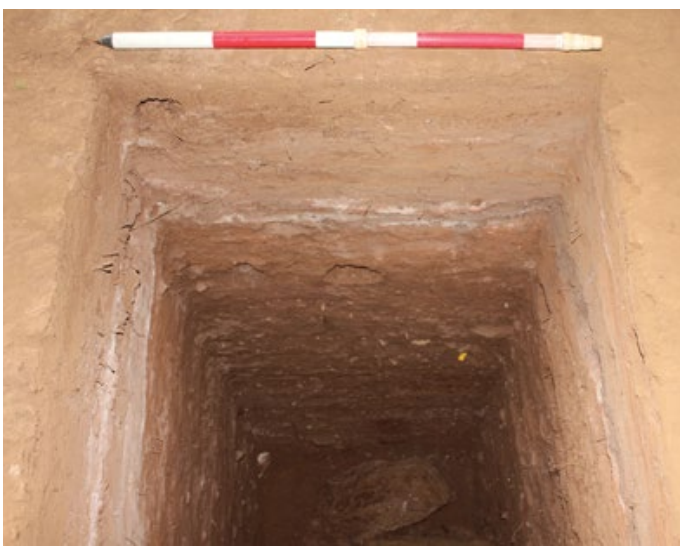

Figure 9.6: Photo of south section of Gua Mo'0 hono showing ash lenses and burnt earth features. Source: Photograph by Sue O'Connor.

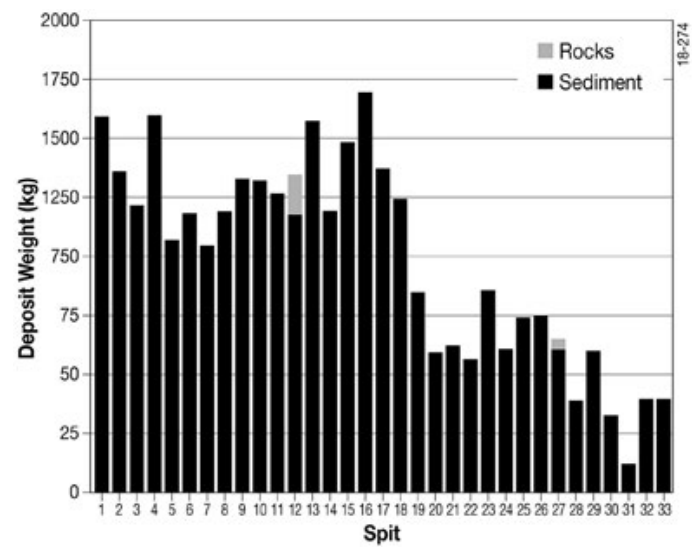

Figure 9.7: Weight of excavated deposit in Gua Mo'o hono by spit.

Source: Authors' data.

\section{Chronology}

The Gua Mo'o hono stratigraphy is anchored by a series of 22 radiocarbon dates, on charcoal and freshwater shell and one bone date (Table 9.1). The purpose of dating both freshwater shell and charcoal from the same test pit (and equivalent spits) was to determine if there is a standard difference in the calibrated ages that could be used as a correction factor for the shell ages. The difference between the intercepts of linear models computed for the ages determined from shell dates and those determined from charcoal is 933 years, indicating that the shell ages overestimate the true ages of deposit formation by about 1000 years. ${ }^{1}$ As a result, the charcoal dates are taken here to provide the more reliable age estimate for the excavation sequence at Gua Mo'o hono (Table 9.1, in bold).

\footnotetext{
1 This is because during life the gastropods likely ingested radiometrically 'old' carbon from the surrounding karst limestone,
} dissolved in the stream water they inhabited (Spriggs 1989). 


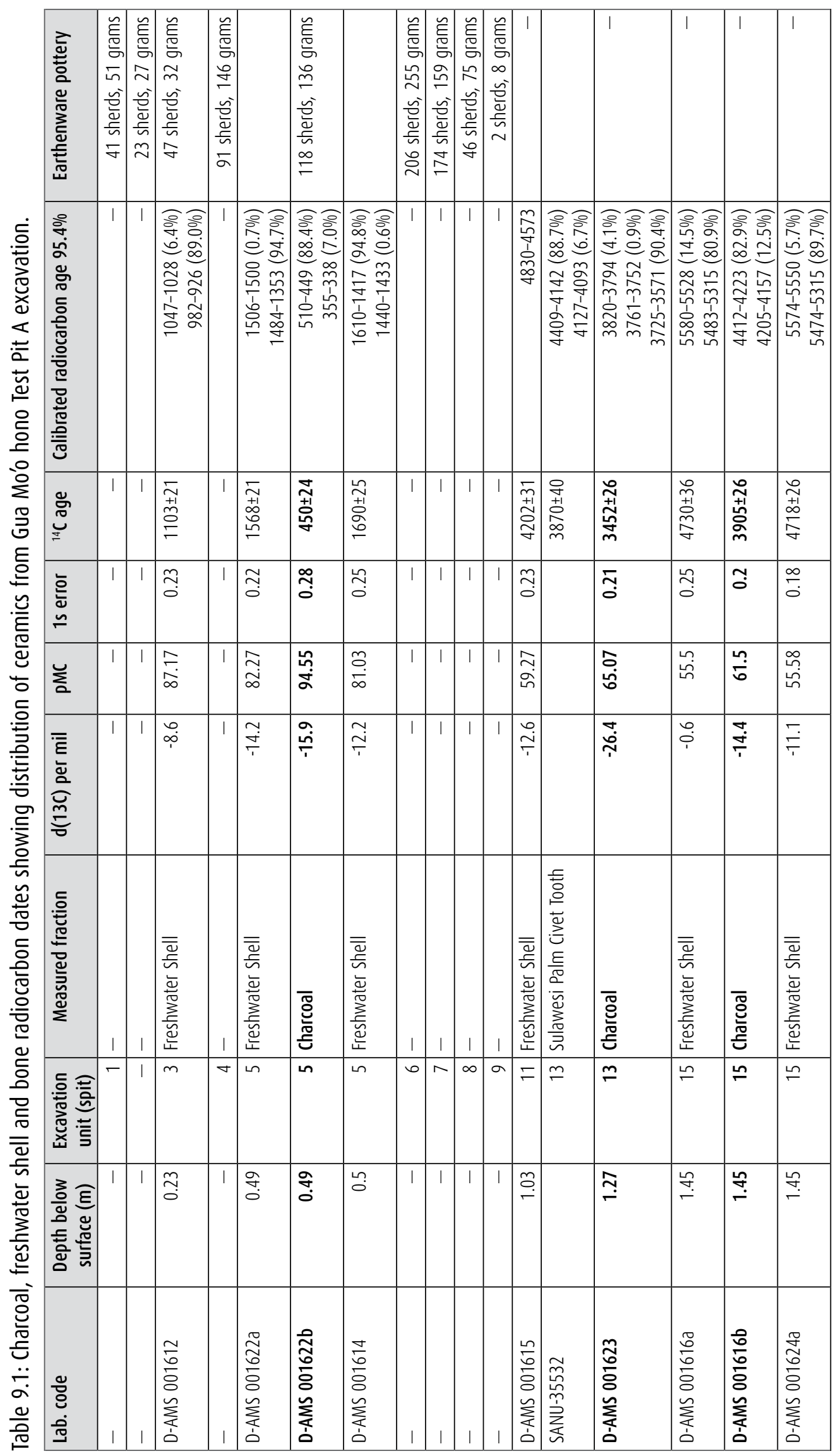


The Archaeology of Sulawesi

\begin{tabular}{|c|c|c|c|c|c|c|c|c|c|c|c|c|c|}
\hline 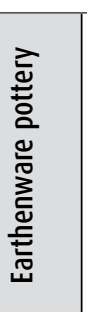 & 1 & 1 & \begin{tabular}{|l|}
1 \\
\end{tabular} & 1 & 1 & & 1 & 11 & 1 & 1 & 1 & 1 & 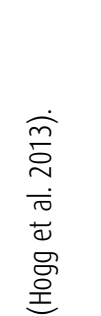 \\
\hline 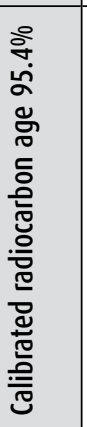 & 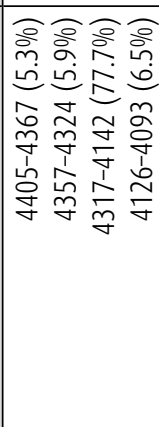 & 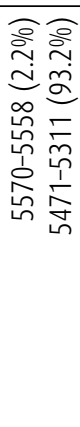 & 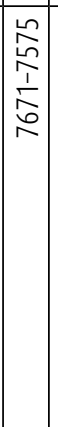 & 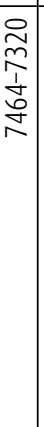 & 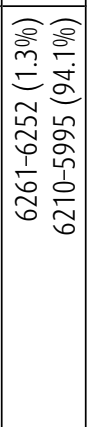 & 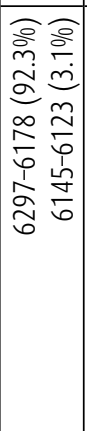 & 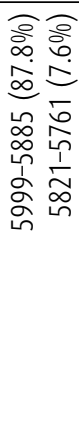 & 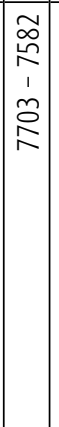 & 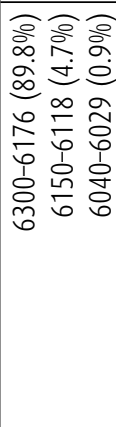 & $\begin{array}{l}\frac{\bar{\sigma}}{0} \\
\frac{1}{\alpha} \\
\frac{\alpha}{2} \\
12\end{array}$ & $\stackrel{\sim}{\pi}$ & 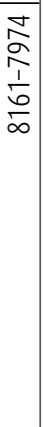 & 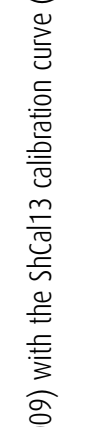 \\
\hline $\begin{array}{l}\stackrel{\mathscr{D}}{0} \\
\text { = }\end{array}$ & 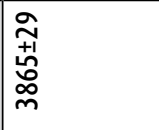 & 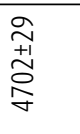 & \begin{tabular}{|c|} 
\\
+1 \\
+1 \\
0 \\
0 \\
0
\end{tabular} & 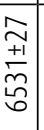 & 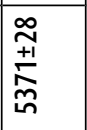 & 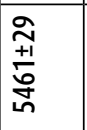 & $\frac{\underset{\sim}{\tilde{N}}}{\underset{\sim}{+}}$ & 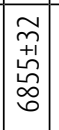 & 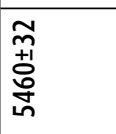 & 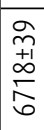 & $\begin{array}{l}\text { Tे } \\
\text { +1 } \\
\infty\end{array}$ & 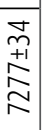 & $\frac{\vec{\sigma}}{\frac{\pi}{\sigma}}$ \\
\hline 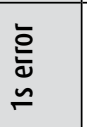 & $\underset{\sim}{\stackrel{N}{O}}$ & ชै & \begin{tabular}{|l|}
$\frac{\pi}{0}$ \\
\end{tabular} & 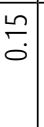 & $\frac{\infty}{0}$ & $\frac{\infty}{0}$ & $\bar{T}$ & $\frac{7}{0}$ & $\widetilde{0}$ & $\underset{\widetilde{N}}{\sigma}$ & $\stackrel{\infty}{0}$ & $\begin{array}{l}\tilde{I} \\
\tilde{0}\end{array}$ & 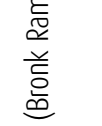 \\
\hline$\sum_{a}^{\breve{a}}$ & $\frac{\Phi}{\infty}$ & $\begin{array}{l}\hat{\sigma} \\
\text { Lें }\end{array}$ & \begin{tabular}{|l|} 
\\
$\infty$ \\
$\mathscr{\gamma}$
\end{tabular} & 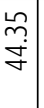 & 沝 & $\begin{array}{l}\text { Tọ } \\
\text { in }\end{array}$ & $\underset{\text { กิ }}{\stackrel{\sim}{n}}$ & $\begin{array}{l} \\
\ddot{\forall}\end{array}$ & $\begin{array}{l}\infty \\
00 \\
\text { in }\end{array}$ & $\mid \begin{array}{l}m \\
\tilde{\vartheta}\end{array}$ & $\begin{array}{l}a \\
\dot{g}\end{array}$ & 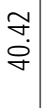 & 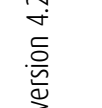 \\
\hline 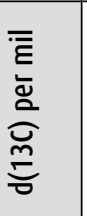 & 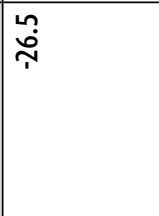 & $\bar{i}$ & \begin{tabular}{|l|} 
\\
$\dot{\sim}$ \\
\end{tabular} & 9 & \begin{tabular}{|l|}
$\underline{n}$ \\
\end{tabular} & $\frac{a}{\grave{\tau}}$ & $\stackrel{m}{\stackrel{m}{\sim}}$ & \begin{tabular}{|l|}
$\infty$ \\
$\stackrel{\infty}{\sim}$ \\
$\stackrel{p}{r}$
\end{tabular} & 㝖 & $\begin{array}{l}\stackrel{0}{\sim} \\
\tilde{m}\end{array}$ & $\frac{0}{1}$ & $\widetilde{\sim}$ & 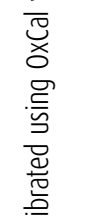 \\
\hline 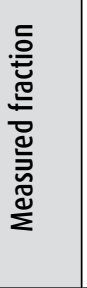 & 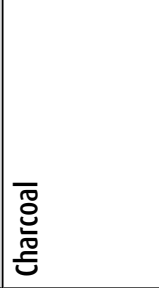 & 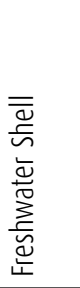 & 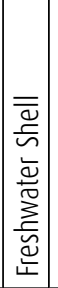 & 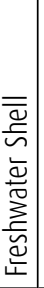 & 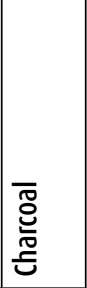 & 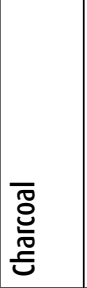 & 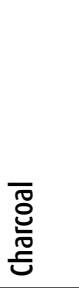 & 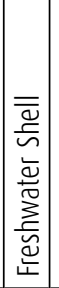 & 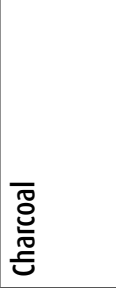 & 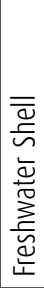 & ¿ & 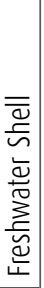 & 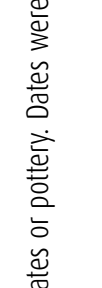 \\
\hline 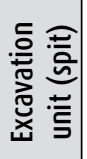 & $\stackrel{n}{\sim}$ & $=$ & \begin{tabular}{|l|}
$\infty$ \\
\end{tabular} & ㄱ. & $\stackrel{\sim}{2}$ & $\stackrel{2}{\sim}$ & $\approx$ & $\lesssim$ & $\lesssim$ & $\bar{m}$ & $\bar{m}$ & $\tilde{m}$ & 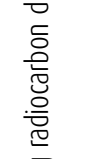 \\
\hline 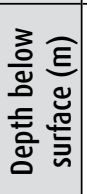 & $\stackrel{\text { 年 }}{\sim}$ & זִ & \begin{tabular}{|l|}
$\infty$ \\
$\infty$ \\
$-\infty$
\end{tabular} & 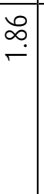 & 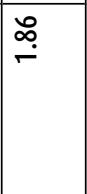 & $\frac{\nabla}{i}$ & $\frac{a}{\bar{i}}$ & $\underset{\sim}{\underset{\sim}{\sim}}$ & $\underset{\sim}{\mathbb{N}}$ & $\underset{\sim}{\stackrel{\leftrightarrow}{\sim}}$ & $\stackrel{n}{\underset{\sim}{\sim}}$ & $\stackrel{\sim}{\sim}$ & 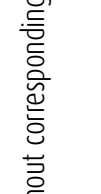 \\
\hline 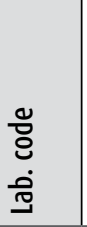 & 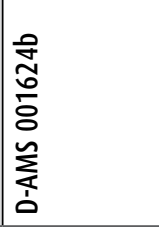 & $\begin{array}{l}\hat{\bar{\sigma}} \\
\overline{8} \\
\sum_{i}^{n} \\
0\end{array}$ & 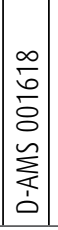 & 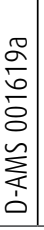 & 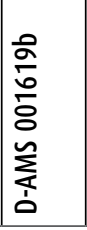 & 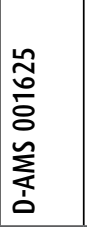 & 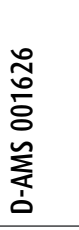 & $\mid \begin{array}{l}2 \\
0 \\
0 \\
0 \\
0 \\
\vdots \\
\vdots \\
\vdots \\
0\end{array}$ & 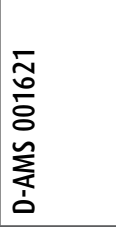 & 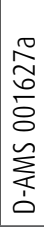 & & 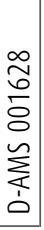 & 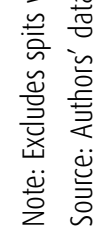 \\
\hline
\end{tabular}


Based on radiometric dating and the material culture, the archaeological stratigraphy from Gua Mo'o hono can be split into three chronological phases, which permits the identification of changes in the archaeological record through time (Figure 9.5; Table 9.1). The upper eight spits $(80 \mathrm{~cm})$ can be distinguished from the rest of the stratigraphic sequence by the presence of pottery. This marks a distinctive change in material culture and perhaps human activity within the last 2000 years of occupation at the site. The sequence is also divided into those deposits below Spit $15(125 \mathrm{~cm})$ that can be confidently assigned to a mid-Holocene age beyond $4500 \mathrm{cal} \mathrm{BP}$; and Spits 9-5 that were deposited in the later Holocene after $4500 \mathrm{cal}$ BP, but before the introduction of pottery.

\section{Sediments}

Field observations and geoarchaeological analysis of the sediments at Gua Mo'o hono indicates that the deposit can be divided into three major depositional units (Appendices A and B; see also Figure 9.6). The upper unit is a crusty yellow-brown surface deposit of silt, probably formed by recent cattle trampling. This unit has high concentrations of soluble salts and organic matter, probably due to the contribution of animal waste and the limited exposure to weathering. The second unit contains several well-preserved hearth features with characteristic sequences of white ash, small lenses of black charcoal and red baked clay. This unit is also distinguished by higher $\mathrm{pH}$ values and concentrations of carbonate minerals and lower concentrations of soluble salts and organic matter. Shells were present in some of the hearths, often broken and burnt. This second unit is interpreted as a result of frequent human activity at the site, especially related to cooking and food preparation. Surrounding the hearths were yellow-brown to red silts and clayey silts. Below this unit was a massive red-brown clayey silt deposit with sparse limestone angular cobbles and rare river cobbles. This unit has higher concentrations of organic matter, lower $\mathrm{pH}$ values and concentrations of soluble salts. This lower unit probably formed by low energy surface water flow transporting fine sediments into the site. The undifferentiated structure of this deposit suggests that substantial bioturbation has occurred, most likely due to the growth of plant roots and termite burrowing.

Comparison of the dates with depth of deposit (Table 9.2) indicates that most of the excavated deposit accumulated during short intervals. The top $55 \mathrm{~cm}$ accumulated within 500 years, the $45 \mathrm{~cm}$ just below $1 \mathrm{~m}$ accumulated within 600 years, and the bottom metre within a millennium. There are two periods whose chronology is poorly documented, corresponding to Spits 6-10 and 15-16. These may reflect periods of slow deposition or, alternatively, they may bracket gaps of up to two millennia in the depositional sequence.

Table 9.2: Summary of the Gua Mo'o hono sedimentary sequence.

\begin{tabular}{|l|l|l|l|}
\hline Spits & Depth & Approximate age span & Summary description of sediments \\
\hline $1-5$ & $0-55 \mathrm{~cm}$ & $0-500 \mathrm{BP}$ & Compacted upper topsoil, hearth features \\
\hline $6-10$ & $55 \mathrm{~cm}-1.05 \mathrm{~m}$ & $>500 \mathrm{BP},<3400 \mathrm{BP}$ & Hearth features in brown sediment \\
\hline $11-14$ & $1.05-1.5 \mathrm{~m}$ & $3400-4500 \mathrm{BP}$ & Massive red-brown clayey silt \\
\hline $15-16$ & $1.5-1.65 \mathrm{~m}$ & $>4500 \mathrm{BP},<6000 \mathrm{BP}$ & Massive red-brown clayey silt \\
\hline $17-33$ & $1.65-2.60 \mathrm{~m}$ & $6000-6500 / 7000 \mathrm{BP}$ & Massive red-brown clayey silt \\
\hline
\end{tabular}

Source: Authors' analysis. 


\section{Imported ceramics and glass}

A rim sherd from a European creamware bowl of about 150 years antiquity was recovered in Spit 1. The stoneware body is white and the crackled glaze is pale yellow. Spit 2 produced a curved sherd of greenish-black bottle glass, weighing around $0.4 \mathrm{~g}$. It would be of a similar age to the European creamware sherd. Spit 6 produced a very small sherd from a Chinese blueand-white porcelain. A dash of greyish-blue decoration is visible both exteriorly and interiorly, beneath the light greenish-grey glaze. The fabric where freshly exposed is pinkish white. This sherd is too small to be firmly diagnostic but may be of Ming antiquity.

\section{Earthenware}

A total of 748 earthenware sherds weighing $889 \mathrm{~g}$ were recovered from Gua Mo'o hono (Table 9.1). Only 111 of these sherds were recovered from Spits 1 to 3, which may reflect occasional use of the shelter in recent centuries by villagers within the site's vicinity. ${ }^{2}$ The majority of the pottery spanned Spits 4 to 8 , and the two small sherds from Spit 9 almost certainly reflect vertical displacement from the pottery concentrations higher in the profile. Even the lowest sherds are $40 \mathrm{~cm}$ above the 4th millennium cal BP date, which corresponded to Spit 13 (Table 9.1). Most of the identifiable vessel forms are jars, but a box rim was observed in Spit 5. As described below, the earthenware assemblage is variable, but there are few clear differences between the sherds in the uppermost and the lower pottery-bearing spits. In summary, it would appear to be a 'Metal Phase' assemblage dating to within the last 2000 years.

Approximately half of the sherds have no macroscopically visible inclusions in their fabric, except perhaps a sparse presence of white, sand-sized particles ('No inclusions' in Table 9.3). Where these white particles (presumably limestone grit) were more prominent, the fabric can be classified as 'white sandy' ( $18 \%$ of sherds), and where the white inclusions were larger, the fabric can be classified as 'white granular' ( $14 \%$ of sherds). A 'grey ware' fabric was also recognised on the basis of a cream to light greyish fabric colour, a relatively rough texture and occasional darkred to black inclusions (11\%). These four fabric varieties occurred essentially throughout the pottery sequence. A small number of sherds with conspicuous red grains in their fabric were also recorded in Spits 5 and 6.

Table 9.3: Fabric varieties recorded for Gua Mo'o hono Test Pit A earthenware pottery (sherds).

\begin{tabular}{|l|r|r|r|r|r|r|}
\hline \multirow{2}{*}{ Spit } & \multicolumn{9}{|c|}{ Fabric variety } & \multirow{2}{*}{$\begin{array}{c}\text { Decorated } \\
\text { sherds }\end{array}$} \\
\cline { 2 - 6 } & No inclusions & White sandy & White granular & $\begin{array}{c}\text { Grey ware (rough texture, } \\
\text { Sparse dark inclusions) }\end{array}$ & Red grained & \\
\hline 1 & $16(39 \%)$ & $5(12 \%)$ & $20(49 \%)$ & - & - & $7(17 \%)$ \\
\hline 2 & $9(39 \%)$ & $6(26 \%)$ & $7(30 \%)$ & $1(4 \%)$ & - & $1(4 \%)$ \\
\hline 3 & $34(72 \%)$ & $1(1 \%)$ & $11(23 \%)$ & $1(4 \%)$ & - & $1(2 \%)$ \\
\hline 4 & $57(63 \%)$ & $13(14 \%)$ & $15(16 \%)$ & $6(7 \%)$ & - & $5(5 \%)$ \\
\hline 5 & $74(63 \%)$ & $10(8 \%)$ & $25(22 \%)$ & $1(1 \%)$ & $8(6 \%)$ & $14(12 \%)$ \\
\hline 6 & $118(58 \%)$ & $10(4 \%)$ & $7(3 \%)$ & $67(33 \%)$ & $4(2 \%)$ & $10(5 \%)$ \\
\hline 7 & $72(41 \%)$ & $80(46 \%)$ & $14(8 \%)$ & $8(5 \%)$ & - & $15(9 \%)$ \\
\hline 8 & $32(70 \%)$ & $6(13 \%)$ & $7(15 \%)$ & $1(2 \%)$ & - & $1(2 \%)$ \\
\hline 9 & - & $2(100 \%)$ & - & - & - & - \\
\hline Total & $412(55 \%)$ & $133(18 \%)$ & $106(14 \%)$ & $85(11 \%)$ & $12(1 \%)$ & $54(7 \%)$ \\
\hline
\end{tabular}

Note: Fabric variety percentages (summed across) may not exactly sum to $100 \%$ due to rounding. Source: David Bulbeck's laboratory data.

2 Gua Mo'o hono was first recorded by the anthropologists McWilliam and Lorenzen (2009) during their survey of the heritage resources of the Routa and Walandawe districts. They noted that the site had been occupied temporarily by the villagers of Walandawe while they were setting up their houses. 
With both the 'no inclusions' sherds, and the assemblage in total, the exterior colour is brown for around $40 \%$, dark brown to very dark brown for about $40 \%$, reddish-brown for about $10 \%$, and dark grey to very dark grey for about $10 \%$ (Table 9.4). The external surface of the white sandy sherds is more often brown $(56 \%)$ than dark to very dark brown $(20 \%)$, whereas the external surface of the white granular sherds is more often brown (59\%) than dark to very dark brown (25\%). 'Grey ware' sherds include a high proportion with a dark to very dark brown exterior surface $(84 \%)$. Finally, the small collection of red-grained sherds includes $25 \%$ with a reddishbrown exterior surface and $17 \%$ with a red exterior surface.

Table 9.4: External colour of Gua Mo'o hono Test Pit A earthenware pottery (sherds).

\begin{tabular}{|l|r|r|r|r|r|r|}
\hline \multirow{2}{*}{$\begin{array}{l}\text { Munsell colour } \\
\text { (external surface) }\end{array}$} & \multicolumn{5}{|c|}{ Fabric variety } & \multirow{2}{*}{ Total } \\
\cline { 2 - 6 } & No inclusions & White sandy & White granular & Grey ware & Red grained & \\
\hline Brown & $152(37 \%)$ & $75(56 \%)$ & $62(59 \%)$ & $24(28 \%)$ & $4(33 \%)$ & $317(42 \%)$ \\
\hline $\begin{array}{l}\text { Dark to very dark } \\
\text { brown }\end{array}$ & $171(42 \%)$ & $27(20 \%)$ & $26(25 \%)$ & $54(84 \%)$ & $2(17 \%)$ & $280(37 \%)$ \\
\hline Reddish-brown & $44(11 \%)$ & $17(13 \%)$ & $7(7 \%)$ & $5(6 \%)$ & $3(25 \%)$ & $76(10 \%)$ \\
\hline Red & $1(<1 \%)$ & $1(1 \%)$ & $1(1 \%)$ & - & $2(17 \%)$ & $5(1 \%)$ \\
\hline $\begin{array}{l}\text { Greyish to dark } \\
\text { greyish-brown }\end{array}$ & - & $2(2 \%)$ & $3(3 \%)$ & - & - & $5(1 \%)$ \\
\hline $\begin{array}{l}\text { Dark to very dark } \\
\text { grey }\end{array}$ & $41(10 \%)$ & $11(8 \%)$ & $6(6 \%)$ & $2(2 \%)$ & $1(8 \%)$ & $61(8 \%)$ \\
\hline Black & $312(100 \%)$ & $133(100 \%)$ & $106(100 \%)$ & $85(100 \%)$ & $12(100 \%)$ & $748(100 \%)$ \\
\hline Total & & - & $1(1 \%)$ & - & - & $4(1 \%)$ \\
\hline
\end{tabular}

Note: Percentages may not sum vertically to exactly $100 \%$ due to rounding.

Source: David Bulbeck's laboratory data.

The Gua Mo'o hono assemblage shows sufficient variety for more than one production centre to have been involved. Whether there were multiple production centres, and whether there were changes over time in terms of the contribution of these centres to the Gua Mo'o hono assemblage, would require chemical analysis of the sherds to determine. However, there is firm evidence for chronological change in the surface treatment of the pottery (Table 9.5). Around $13 \%$ of the sherds had a lustrous external finish that would seem to have resulted from application of dammar resin (Figure 9.8B) (Bulbeck et al. 2016). The proportion of sherds treated this way was 17-39\% in the uppermost and bottom spits, contrasting with $0-9 \%$ in Spits 3 to 6 . The middle of the pottery sequence included the only sherds with definite or possible red slipping on their external surface. This was particularly pronounced in Spit 5 (Figure 9.8E-H) where $18 \%$ of the sherds were clearly or possibly red-slipped. Dammar coating and red slipping were recorded for all fabric varieties, with the single exception that none of the small assemblage of red-grained sherds presented signs of dammar coating. Finally, there is also some indication of a trend to increased burnishing of the pottery's external surface over time. 
Table 9.5: External surface treatment of Gua Mo'o hono Test Pit A earthenware sherds.

\begin{tabular}{|l|r|r|r|r|r|r|}
\hline Spit & Dammar coated & \multicolumn{1}{|c|}{ Red slipped } & \multicolumn{1}{|c|}{$\begin{array}{c}\text { Possibly } \\
\text { red-slipped }\end{array}$} & \multicolumn{1}{c|}{ Burnished } & \multicolumn{1}{c|}{$\begin{array}{l}\text { No special } \\
\text { treatment }\end{array}$} & \multicolumn{1}{l}{ Total } \\
\hline 1 & $16(39 \%)^{*}$ & - & - & $10(24 \%)$ & $15(37 \%)^{*}$ & $41(100 \%)$ \\
\hline 2 & $7(30 \%)$ & - & - & $1(4 \%)$ & $15(65 \%)^{*}$ & $23(100 \%)$ \\
\hline 3 & - & - & - & $2(4 \%)$ & $45(96 \%)^{*}$ & $47(100 \%)$ \\
\hline 4 & $8(9 \%)^{*}$ & - & $1(1 \%)$ & $4(4 \%)$ & $78(86 \%)^{*}$ & $91(100 \%)$ \\
\hline 5 & $2(2 \%)$ & $14(12 \%)^{*}$ & $6(5 \%)$ & $1(1 \%)$ & $95(80 \%)$ & $118(100 \%)$ \\
\hline 6 & $9(4 \%)$ & $1(1 \%)$ & $1(1 \%)$ & $1(1 \%)$ & $194(94 \%)^{*}$ & $206(100 \%)$ \\
\hline 7 & $49(28 \%)^{*}$ & - & $2(1 \%)$ & - & $123(71 \%)^{*}$ & $174(100 \%)$ \\
\hline 8 & $8(17 \%)$ & - & - & - & $38(83 \%)^{*}$ & $46(100 \%)$ \\
\hline 9 & - & - & - & - & $2(100 \%)^{*}$ & $2(100 \%)$ \\
\hline Total & $99(13 \%)$ & $15(2 \%)$ & $10(1 \%)$ & $19(3 \%)$ & $605(81 \%)$ & $748(100 \%)$ \\
\hline
\end{tabular}

" Recorded for at least one sherd from every fabric variety in the spit.

Note: Percentages may not sum horizontally to exactly 100\% due to rounding.

Source: David Bulbeck's laboratory data.

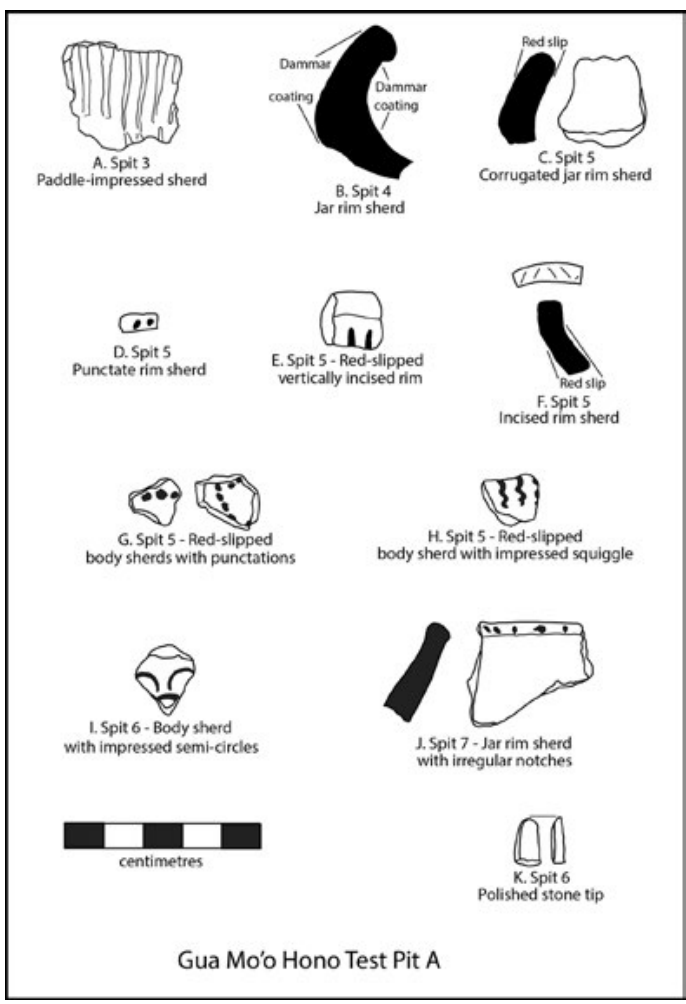

Figure 9.8: Gua Mo'o hono decorated pottery and rims $(A-J)$ and polished stone tip $(K)$.

Source: David Bulbeck's laboratory notes.
As for forming techniques, approximately $20 \%$ of the sherds were recorded as having traces of internal dimpling and/or external paddleimpressed designs (Figure 9.8A), which would appear to reflect use of a paddle and anvil in forming or at least finishing the vessels. Sherds with these characteristics were recorded for every spit, and also for $17-33 \%$ of all fabric varieties (Table 9.6). Wheel lines were observed on nine sherds, including the only identified sherd from a cover, and otherwise a small proportion of the rim, neck, shoulder and body sherds. These wheel lines appear to reflect the occasional use of a slow wheel to finish vessels prior to being fired. Of particular interest are 16 sherds with a ribbed rim, or diamond or quadrilateral designs on the body, that appear to have been achieved by pressing the clay into a mould, such as a basketry casing, although they could possibly be produced by the use of a stamp (Figure 9.9). Sherds from these vessels were recorded in Spits 1, 6, 7 and 8. Finally, the majority of the sherds did not present a clear indication of how they were formed (Table 9.6), but it probably involved some use of a paddle in a way that did not leave obvious traces of the manufacturing method involved. 
Table 9.6: Forming techniques observed on Gua Mo'o hono Test Pit A earthenware pottery (sherds).

\begin{tabular}{|l|r|r|r|r|r|r|}
\hline \multirow{2}{*}{ Production technique } & \multicolumn{5}{|c|}{ Fabric variety } & \multirow{2}{*}{ Total } \\
\cline { 2 - 6 } & No inclusions & White sandy & White granular & Grey ware & Red grained & \\
\hline Paddle and anvil & $72(18 \%)$ & $22(17 \%)$ & $35(33 \%)$ & $25(29 \%)$ & $2(17 \%)$ & $156(21 \%)$ \\
\hline Slow wheel & $6(2 \%)$ & - & $2(2 \%)$ & - & $1(8 \%)$ & $9(1 \%)$ \\
\hline Moulded/stamped & $4(1 \%)$ & $9(7 \%)$ & $3(3 \%)$ & - & - & $16(2 \%)$ \\
\hline No observations & $330(80 \%)$ & $102(77 \%)$ & $66(62 \%)$ & $60(71 \%)$ & $9(75 \%)$ & $567(76 \%)$ \\
\hline Total & $412(100 \%)$ & $133(100 \%)$ & $106(100 \%)$ & $85(100 \%)$ & $12(100 \%)$ & $748(100 \%)$ \\
\hline
\end{tabular}

Note: Percentages may not sum vertically to exactly $100 \%$ due to rounding.

Source: David Bulbeck's laboratory data.

A

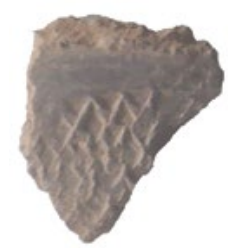

B

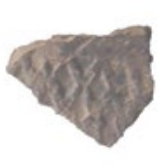

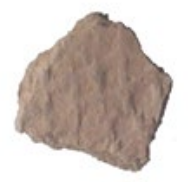

Figure 9.9: Gua Mo'o hono decorated pottery.

A) White sandy earthenware shoulder sherds with mould or stamp produced diamond designs, Spit 7. B) White sandy earthenware body sherd with mould or stamp produced quadrilateral design, Spit 8. C) High-fired, white granular earthenware rim sherd with mould-produced external ribbing, Spit 6.

Source: Photograph by David Bulbeck.

Around $7 \%$ of the sherds were decorated, with a variety of techniques. In addition to the moulded/stamped designs recorded from Spits 1 to 8 , paddle-impressed designs (Figure 9.8A) were recorded from Spits 1 to 7 . This was the most common decoration technique, recorded on 20 of the 54 decorated sherds (37\%). Other recorded techniques include incised horizontal, vertical and slanting lines (Figure 9.8E-F), recorded in Spits 5 and 6; impressed diamonds, squiggles and semi-circles, recorded in Spits 4 to 6 (Figure 9.8H-I); punctate circles in Spit 5 (Figure 9.8D and 9.8G); notches, recorded in Spits 5 and 7 (Figure 9.8J); vertical gouges, recorded in Spit 1; a corrugated rim in Spit 5; and a bossed rim in Spit 7.

\section{Polished stone artefacts}

Spit 6 produced a polished stone tip, $11 \mathrm{~mm}$ long, $5 \mathrm{~mm}$ wide and $3 \mathrm{~mm}$ thick (Figure $9.8 \mathrm{~K}$ ). The stone is fine and siliceous, and dark brown with traces of banding. Spit 6 also produced a rim fragment to a polished stone container, weighing $22 \mathrm{~g}$ (Figure 9.10). The extant shape is more consistent with a square box than a curved jar. Rim thickness is approximately $12 \mathrm{~cm}$, although thickness increased beneath the rim up to $17 \mathrm{~mm}$.

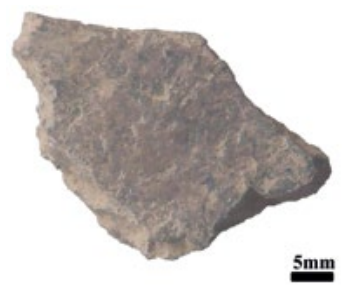

Figure 9.10: Gua Mo'o hono stone box rim fragment, internal view Spit 6.

Source: Photograph by David Bulbeck. 


\section{Flaked stone artefacts}

Approximately 13,506 flaked stone artefacts were recovered from Gua Mo'o hono (Figure 9.11; Table 9.7). The artefacts are almost entirely manufactured from nodules of high-quality chert, typical of other assemblages in Sulawesi. Very small amounts of white quartz and chalcedony are also present. The flake assemblage reflects extensive reduction with little to no cortex remaining on most pieces. The median mass of complete flakes is $1 \mathrm{~g}$ and shows no significant changes between spits. The median mass of cores is $13 \mathrm{~g}$ and also shows no significant change over time. There are two broken cobbles of coarse-grained igneous material with pitting on their flat surface, indicating use as anvils. A further two cobbles have been bifacially flaked, one with extensive polish, indicating the use of grinding to sharpen the working edge (Spit 11).

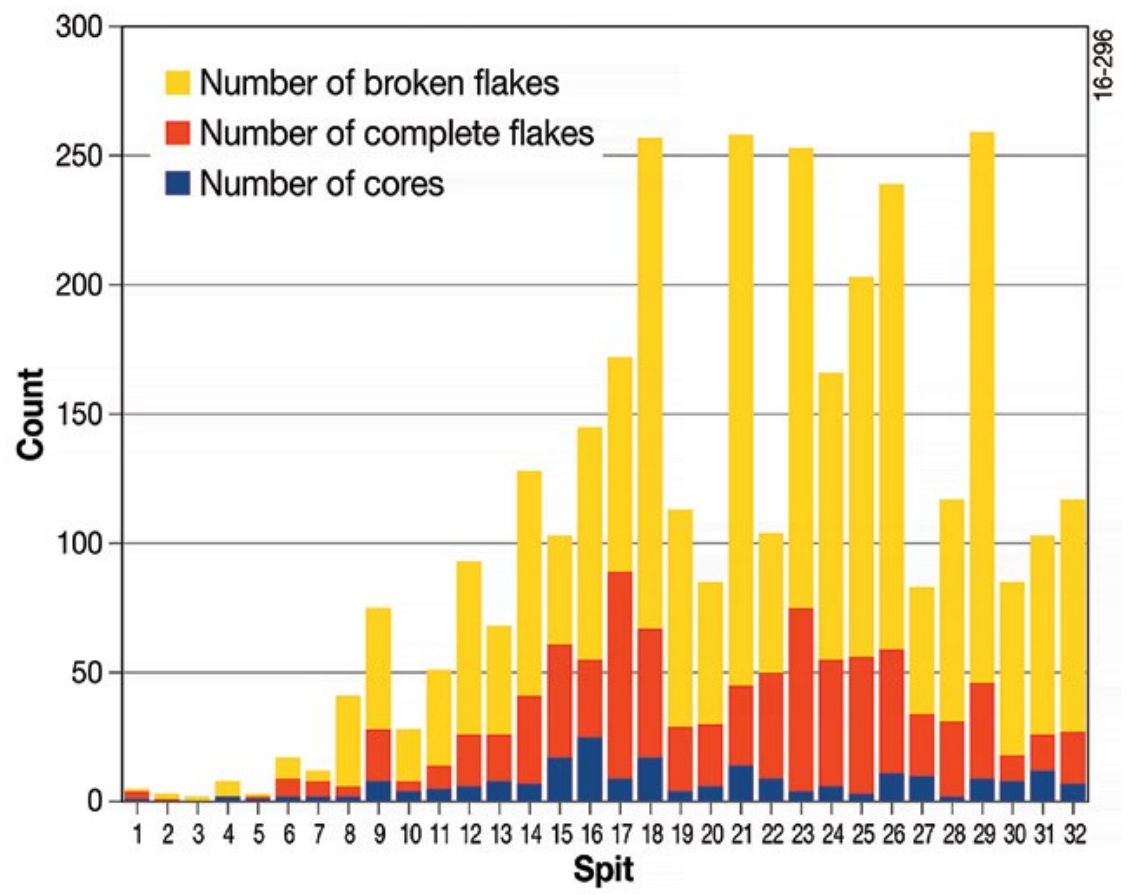

Figure 9.11: Number of cores, flakes and broken flakes in Gua Mo'o hono by spit.

Source: Ben Marwick's laboratory data.

Table 9.7: Counts of flaked stone artefacts in each spit.

\begin{tabular}{|l|r|r|r|}
\hline Spit & Number of complete flakes & Number of broken flakes & Number of cores \\
\hline 1 & 3 & 1 & 1 \\
\hline 2 & 1 & 2 & 0 \\
\hline 3 & 0 & 2 & 0 \\
\hline 4 & 0 & 6 & 2 \\
\hline 5 & 1 & 1 & 1 \\
\hline 6 & 7 & 8 & 2 \\
\hline 7 & 6 & 4 & 2 \\
\hline 8 & 4 & 35 & 2 \\
\hline 9 & 20 & 47 & 8 \\
\hline 10 & 4 & 20 & 4 \\
\hline 11 & 9 & 37 & 5 \\
\hline 12 & 20 & 67 & 6 \\
\hline 13 & 18 & 42 & 8 \\
\hline
\end{tabular}




\begin{tabular}{|l|r|r|r|}
\hline Spit & Number of complete flakes & Number of broken flakes & Number of cores \\
\hline 14 & 34 & 87 & 7 \\
\hline 15 & 44 & 42 & 17 \\
\hline 16 & 30 & 90 & 25 \\
\hline 17 & 80 & 83 & 9 \\
\hline 18 & 50 & 190 & 17 \\
\hline 19 & 25 & 84 & 4 \\
\hline 20 & 24 & 55 & 6 \\
\hline 21 & 31 & 213 & 14 \\
\hline 22 & 41 & 54 & 9 \\
\hline 23 & 71 & 178 & 4 \\
\hline 24 & 49 & 111 & 6 \\
\hline 25 & 53 & 147 & 3 \\
\hline 26 & 48 & 180 & 11 \\
\hline 27 & 24 & 49 & 10 \\
\hline 28 & 29 & 86 & 2 \\
\hline 29 & 37 & 213 & 9 \\
\hline 30 & 10 & 67 & 8 \\
\hline 31 & 14 & 77 & 12 \\
\hline 32 & 20 & 90 & 7 \\
\hline
\end{tabular}

Source: Ben Marwick's laboratory data.

Bayesian change point analysis indicates that the majority of artefacts were discarded between Spits 18 to 29, with very few in the pottery-bearing spits (1-8). The low level of lithic discard in the more recent spits is probably because of the appearance of other technologies such as metal and ceramics. The interval of highest discard corresponds to calibrated dates of around 6000-6300 cal BP (Table 9.1), indicating a relatively short period for the deposition of most of the artefacts at this site. Curiously, this period overlaps with the peak of Maros points in Ulu Leang site in South Sulawesi (Glover and Presland 1985), suggesting this was a time when stone artefact production was high across Sulawesi.

\section{Retouched stone artefacts}

Retouched tools are rare, comprising $<1 \%$ of the assemblage $(\mathrm{n}=31)$ and show no recurring formal types. Retouching is most frequently found around the distal region of flakes. Notches and beak-like retouch are present on scrapers but rare. Notable absences from the Gua Mo'o hono assemblage are the geometric microliths and other backed artefacts that characterise the Toalean assemblages of South Sulawesi (Bulbeck et al. 2000). Maros points, with their distinctive isosceles triangular shape, denticulate or biface edges and hollow base (Glover and Presland 1985) were not found in the Gua Mo'o hono assemblage. The absence of these forms of stone artefacts from this site lends some support to the claim by Bulbeck et al. (2000) that the Toalean assemblages may have been made only by a group localised to the southwest of the South Sulawesi peninsula and perhaps culturally and linguistically distant from communities occupying other parts of Sulawesi including the occupants of Gua Mo'o hono.

Figure 9.12 shows a representative selection of retouched stone artefacts from Gua Mo'o hono. Artefact 12(a) from Spit 9 is retouched around the entire perimeter of the piece. The retouch is steep, multiple-layered, feather-terminated scars, overlain by small crushing fractures in many parts of the margin. These traces are consistent with deliberate shaping and resharpening of the artefact combined with probable use-wear damage on some parts of the margin. It features an unusual tang or waist geometry formed by two asymmetric notches. Small crushing fractures are 
visible in the notches, suggesting they were edges used to perform work, such as shaving wood. In light of this use-wear in the notches, the asymmetric relationship of the notches, and the thickness of the artefact, the tang-like appearance of this artefact is probably coincidental and does not indicate that the piece was a hafted point. Artefact 12(b) shows the same combination of retouch and use-wear as Artefact 12(a), with small, steep, overlapping feather-terminated scars overlain by crushing use-wear, but the retouch is limited to part of one margin.

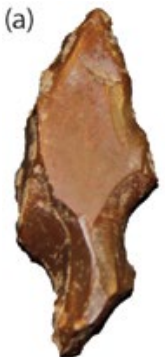

(c)

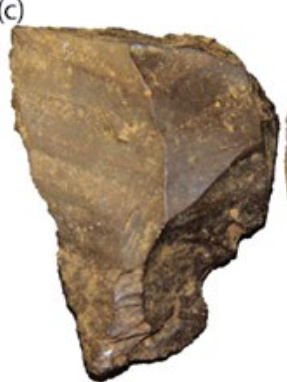

(e)

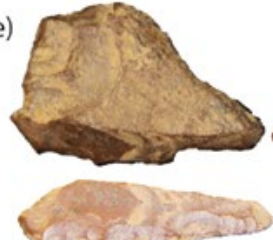

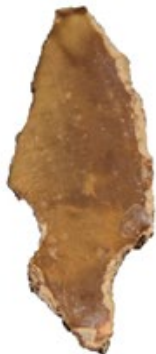

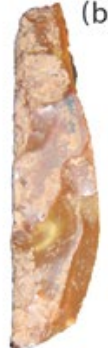

(b)
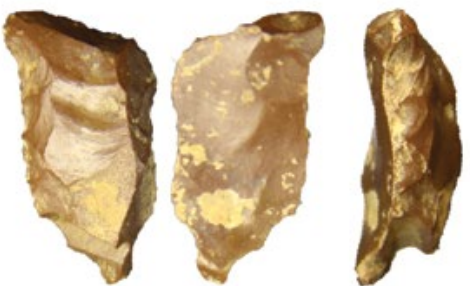

(d)
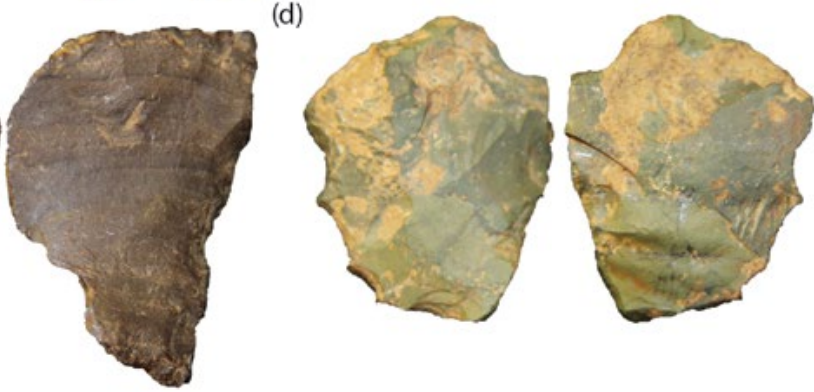

(g)

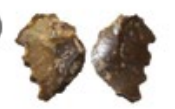

Figure 9.12: Selection of retouched artefacts from Gua Mo'o hono.

(a) Spit 9 (5005); (b) Spit 10 (5009); (c) Spit 27 (2111); (d) Spit 11 (0035); (e) Spit 9 (5004); (f) Spit 9 (5009); (g) Spit 8 (5003). Source: Photograph by Ben Marwick.

Artefacts 12(a), (b) and (e) were recovered from Spits 9 and 10, the two spits that contained the most retouched pieces. Artefact 12(e) shows a pattern of retouch similar to 12(a) and (b), but is an end-scraper, with the retouched edge located on the distal margin of the flake, which is the longest margin on this flake. Artefact 12(c) was found in Spit 27, and is among the earliest retouched pieces at Gua Mo'o hono (the earliest appeared in Spit 32). Artefact 12(c) shows a slightly different approach to retouch with retouch flakes removed off the ventral and dorsal surfaces of the artefact, rather than only the dorsal surface, as seen on Artefacts 12(a) and (b). Artefact 12(c) has a small notch on the dorsal surface, and on the opposite margin a short length of retouch following the same pattern as the other artefacts. The raw material is a siliceous bedded sedimentary rock, and a small area of cortex is present, unlike the majority of retouched pieces, which are highly siliceous chert with no cortex. This piece illustrates some of the diversity among the retouched pieces, suggesting that the selection of nodules for flaking and retouching was not tightly constrained. Artefact 12(d) from Spit 11 further demonstrates this diversity with a series of shallow notches along one margin. Artefacts $12(\mathrm{f})$ and $(\mathrm{g})$, from Spits 8 and 9, also show notching on a single margin similar to Artefact 12(d). The notches on Artefacts 12(f) and $12(\mathrm{~g})$ are deeper and more concave, suggesting the edges of these artefacts were serrated to use as a saw-like tool.

\section{terira australis 48}




\section{Cores}

Most cores are made from chert, and all show signs of extensive reduction, with an average $10 \%$ cortex. They are typically very small, with an average mass around $24 \mathrm{~g}$, and most appear to be broken, with truncated scars on many pieces. Most cores have single or multiple platforms, with a small number of radial and prismatic cores. Bipolar anvil-rested reduction techniques are evident in the form of flake scars with opposing initiations and crushing at both ends. The overall impression we have from the cores discarded at the site is that raw material nodules were probably small when they were acquired, sourced from small fragmented seams and outcrops near the site, and flaking continued until the cores were too small to easily manage. The use of bipolar techniques represents efforts by the knappers to extend the useful life of the cores beyond what can be easily managed by freehand direct percussion (Hiscock 2015).

Figure 9.13 shows a sample of cores from Gua Mo'o hono. Artefacts 13(a), 13(b), and 13(e) show flake scars of small blade-like removals, but 13 (a) and 13(c) also show aberrant terminations, suggesting that the core was at a stage where the knapper found it difficult to remove complete flakes. Artefacts 13(b) and 13(e) display bipolar traces, with flake removals initiated from the top and bottom of the core. Artefact 13(e) also has a third platform orthogonal to the bipolar axis. Artefact 13(d) shows a truncated ventral surface, where a relatively large flake was broken and then the ventral surface used as a platform for flake removals. This technique is rare in this assemblage, but has been documented elsewhere in Indonesia, such as Jerimalai (Marwick, pers. observation) and Liang Bua (Moore et al. 2009). Artefact 13(f) is similarly a flake fragment that has subsequently had some small flakes removed. Taken together, the signs of extensive reduction on these cores indicate that raw material conservation was a high priority in using stone at this location.

(a)

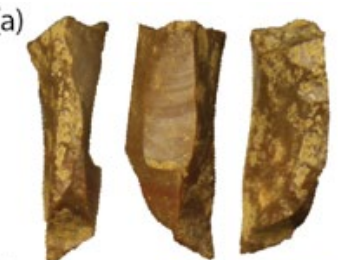

(d)
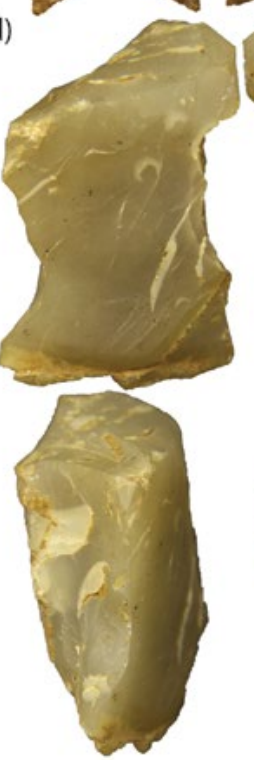

(b)

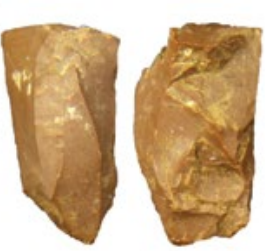

(e)

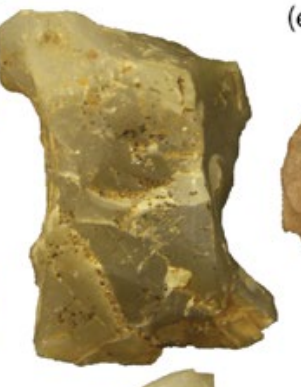

(c)
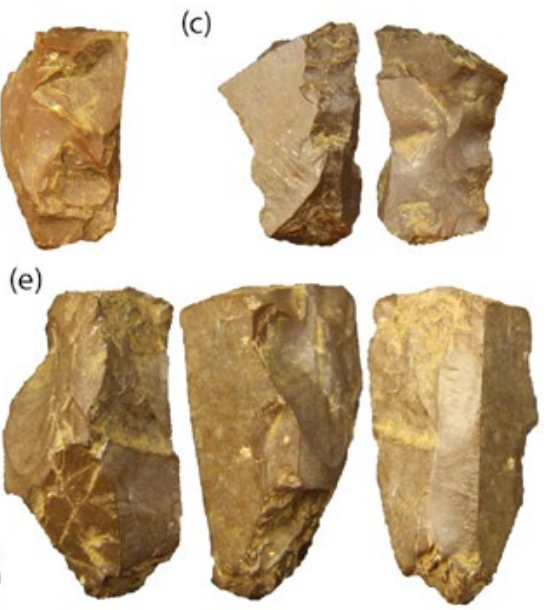

(f)

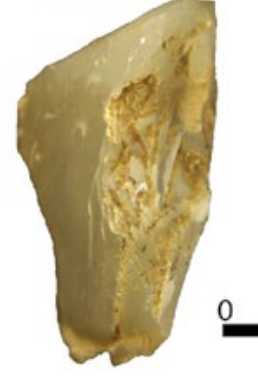

Figure 9.13: Selection of cores from Gua Mo'o hono.

(a) Spit 32 (5026); (b) Spit 15 (1031; (c) Sit 9 (1009); (d) Spit 11 (1016); (e) Spit 18 (1021); (f) Spit 18 (1025). Source: Photograph by Ben Marwick. 


\section{Human remains}

Of considerable interest are the fragmentary human remains from Spits 19, 23 and 26, at a stratigraphic level corresponding to around $6000 \mathrm{cal} \mathrm{BP}$ (Table 9.1). Including a deciduous first molar from Spit 14, a minimum number of three individuals are represented. An attempt to directly date the mandible from Spit 19 was abandoned when an assay by Rachel Wood determined that the carbon content would probably be too low to produce a reliable determination.

Two joining fragments from an adult human mandible were recovered from Spit 19 (Figure 9.14). The extant mandible is small, as can be seen by comparing its available measurements with those of other Sulawesi mandibles (Table 9.8), and so is probably female. The mandible is gracile in terms of the anatomical features described by Larnach and Macintosh (1971). The mental trigone, submental notch, fossa mentalis, basal trigone, anterior marginal tubercle and superior transverse torus are all slight. Additional features recorded in the chin region include medium anterior incurvature, a slightly declined alveolar plane, small genial spines and

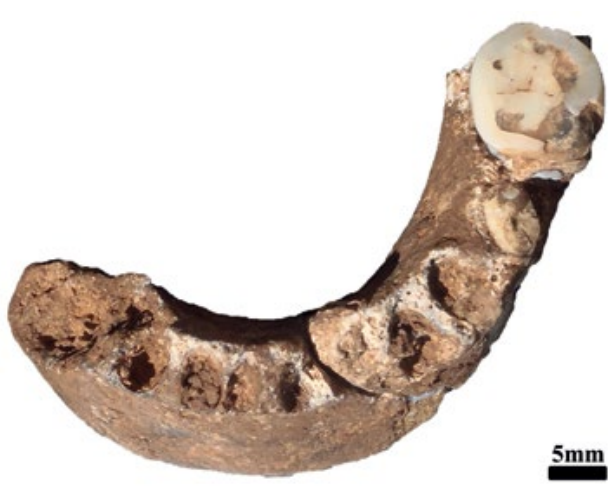

Figure 9.14: Gua Mo'o hono mandible fragment with Spit 19 first left lower molar fitted into place. Source: Photograph by David Bulbeck. the absence of a genial pit.

Table 9.8: Measurements on the Gua Mo'o hono mandible fragment.

\begin{tabular}{|c|c|c|c|c|}
\hline Measurement ${ }^{(\mathrm{a})}$ & Gua Mo'o hono & Toaleans $^{(b)}$ & Sulawesi males ${ }^{(c)}$ & Sulawesi females $(c)$ \\
\hline Chin height (h1) & 27 & 32 & $\begin{array}{r}30.0 \\
(22-36)\end{array}$ & 28 \\
\hline Symphysis height & 28 & - & $\begin{array}{r}31.1 \\
(23-37) \\
\end{array}$ & $\begin{array}{r}31.1 \\
(28.5-34.5) \\
\end{array}$ \\
\hline Symphysis thickness & 12 & - & $\begin{array}{r}14.2 \\
(12-15.5)\end{array}$ & $\begin{array}{r}13.6 \\
(11-16.5)\end{array}$ \\
\hline Height at first premolar (p1h) & 28 & 31 & $\begin{array}{r}31.9 \\
(29-35) \\
\end{array}$ & $\begin{array}{r}27.3 \\
(24.5,30) \\
\end{array}$ \\
\hline $\begin{array}{l}\text { Corpus height at mental foramen } \\
(\text { M69(1)) }\end{array}$ & $\sim 29$ & $30.5-31.5$ & $\begin{array}{r}28.9 \\
(25-33) \\
\end{array}$ & $\begin{array}{r}26.3 \\
(24-29) \\
\end{array}$ \\
\hline $\begin{array}{l}\text { Corpus thickness at mental foramen } \\
(\text { M69(3)) }\end{array}$ & 12 & $11-14$ & $\begin{array}{r}12.5 \\
(9-17) \\
\end{array}$ & $\begin{array}{r}11.0 \\
(9.5-13)\end{array}$ \\
\hline Bimental breadth (zz) & $\sim 40$ & 48 & $\begin{array}{r}47.8 \\
(44.5-55)\end{array}$ & $\begin{array}{r}41.7 \\
(38-45)\end{array}$ \\
\hline
\end{tabular}

(a) Definitions: h1, p1h, zz (Morant 1923); symphysis height and thickness (Brown 1989); M69(1) and M69(3) (Bräuer 1988).

(b) Two mid-Holocene mandibles from Southwest Sulawesi (Bulbeck 2004).

(c) Ethnographic museum specimens and archaeological sites less than 1500 years old-maximum sample size $16 \hat{\delta}, 5$, Bulbeck (unpublished).

Source: David Bulbeck's laboratory data.

The alveoli are present for all of the incisors, both canines and the left first premolar, which had evidently been lost prior to the individual's death. The left second premolar appears to have been recently sheared off, but no trace of it was found in the excavated material. However, a left mandibular first molar from Spit 19, whose moderate tooth wear corresponds to Smith's stage 4 (Hillson 1996:Figure 11.1), can be fitted back onto the mandible. 
The teeth from Spits 23 and 26 represent a minimum of two individuals. Eight of the nine teeth from Spit 23, and the tooth from Spit 26, are extremely worn, with degrees of occlusal wear between Smith's stages 5 and 7 (Hillson 1996:Figure 11.1). They would appear to represent an adult of moderate to advanced age, depending on the rate of occlusion experienced by this mid-Holocene forager. Accordingly, in most cases tooth size could be gauged only by taking the diameters at the cemento-enamel junction (Table 9.10). Fortunately, the ethnohistorical Gua Andomo and Gua Lampetia burials (Bulbeck et al. 2016) were also recorded for their tooth diameters at the cemento-enamel junction, allowing a comparison to be made. There was also a right second premolar tooth bud recovered from Spit 23, corresponding to a child of about five years of age (cf. Hillson 1996).

The available metrical data do not allow for a clear distinction in tooth size between the study region's mid-Holocene and ethnohistorical inhabitants (Tables 9.9 and 9.10). In some cases, the mid-Holocene tooth diameter lies above the ethnohistorical range, as in the $\mathrm{P}^{2}$ length and the cemento-enamel junction diameters for the lower incisors and the $\mathrm{M}^{1}$ length. However, there are also cases where the mid-Holocene tooth diameter falls below the ethnohistorical range, as in the $\mathrm{M}^{2}$ cemento-enamel junction breadth.

Table 9.9: Gua Mo'o hono occlusal diameters (mm) compared with the Gua Lampetia/Gua Andomo means and ranges.

\begin{tabular}{|l|l|r|r|r|r|r|r|}
\hline & & \multicolumn{2}{|c|}{ Gua Mo'o hono spits } & \multicolumn{3}{c|}{ Gua Lampetia/Gua Andomo } \\
\hline \multirow{2}{*}{ Tooth } & Diameter & 19 & \multicolumn{1}{|c|}{23} & \multicolumn{1}{c|}{ 26 } & Sample size & \multicolumn{1}{c|}{ Mean } & \multicolumn{1}{c|}{ Range } \\
\hline \multirow{2}{*}{ P2 } & Mesio-distal length & & 8.5 & & 8 & 7.0 & $6.5-7.6$ \\
\cline { 2 - 8 } & Bucco-lingual breadth & & 9.3 & & 8 & 9.5 & $9.1-10.5$ \\
\hline \multirow{2}{*}{$M_{2}$} & Mesio-distal length & 11.0 & & & 12 & 11.2 & $10.0-11.7$ \\
\cline { 2 - 8 } & Bucco-lingual breadth & 11.0 & & 9.3 & 12 & 10.3 & $9.7-10.6$ \\
\hline
\end{tabular}

Source: David Bulbeck's laboratory data.

Table 9.10: Gua Mo'o hono diameters at the cemento-enamel junction (mm) compared with the Gua Lampetia/Gua Andomo means and ranges.

\begin{tabular}{|c|c|c|c|c|c|c|c|}
\hline \multirow[b]{2}{*}{ Tooth } & \multirow[b]{2}{*}{ Diameter } & \multicolumn{3}{|c|}{ Gua Mo'o hono spits } & \multicolumn{3}{|c|}{ Gua Lampetia/Gua Andomo } \\
\hline & & 19 & 23 & 26 & Sample size & Mean & Range \\
\hline \multirow[t]{2}{*}{$I_{1}$} & Mesio-distal length & & 5.4 & & 8 & 4.3 & $3.8-4.8$ \\
\hline & Bucco-lingual breadth & & 7.8 & & 7 & 6.3 & $5.9-7.6$ \\
\hline \multirow[t]{2}{*}{$I_{2}^{(a)}$} & Mesio-distal length & & 5.1 & & 10 & 4.4 & $3.5-5.1$ \\
\hline & Bucco-lingual breadth & & 7.4 & & 10 & 5.9 & $5.5-6.6$ \\
\hline \multirow[t]{2}{*}{$M_{1}$} & Mesio-distal length & & 9.5 & & 8 & 10.4 & $9.5-10.9$ \\
\hline & Bucco-lingual breadth & & 9.1 & & 8 & 9.8 & $9.1-10.6$ \\
\hline \multirow[t]{2}{*}{$M_{2}$} & Mesio-distal length & 10.0 & 9.7 & & 11 & 9.9 & $9.2-10.7$ \\
\hline & Bucco-lingual breadth & 9.6 & 8.8 & 8.5 & 11 & 9.6 & $8.5-10.5$ \\
\hline$M_{3}$ & Mesio-distal length & & 9.4 & & 2 & 9.5 & $8.9-10.1$ \\
\hline \multirow[t]{2}{*}{$M^{1}$} & Mesio-distal length & & 9.6 & & 8 & 8.6 & $8.0-9.5$ \\
\hline & Bucco-lingual breadth & & 10.4 & & 8 & 11.3 & $10.3-12.4$ \\
\hline \multirow[t]{2}{*}{$M^{2}$} & Mesio-distal length & & 9.5 & & 9 & 8.3 & $7.0-9.6$ \\
\hline & Bucco-lingual breadth & & 9.7 & & 9 & 11.0 & $10.0-13.0$ \\
\hline
\end{tabular}

(a) Both right and left lower second incisors are present, with identical measurements.

Source: David Bulbeck's laboratory data. 


\section{Fauna: Freshwater gastropods}

Freshwater gastropods were found throughout the Gua Mo'o hono sequence and in places occurred in dense lenses (Figure 9.5 south section). Shell was most abundant in the upper units and decreased in the red-brown clayey silt no doubt due to poor preservation with depth (Figure 9.15).

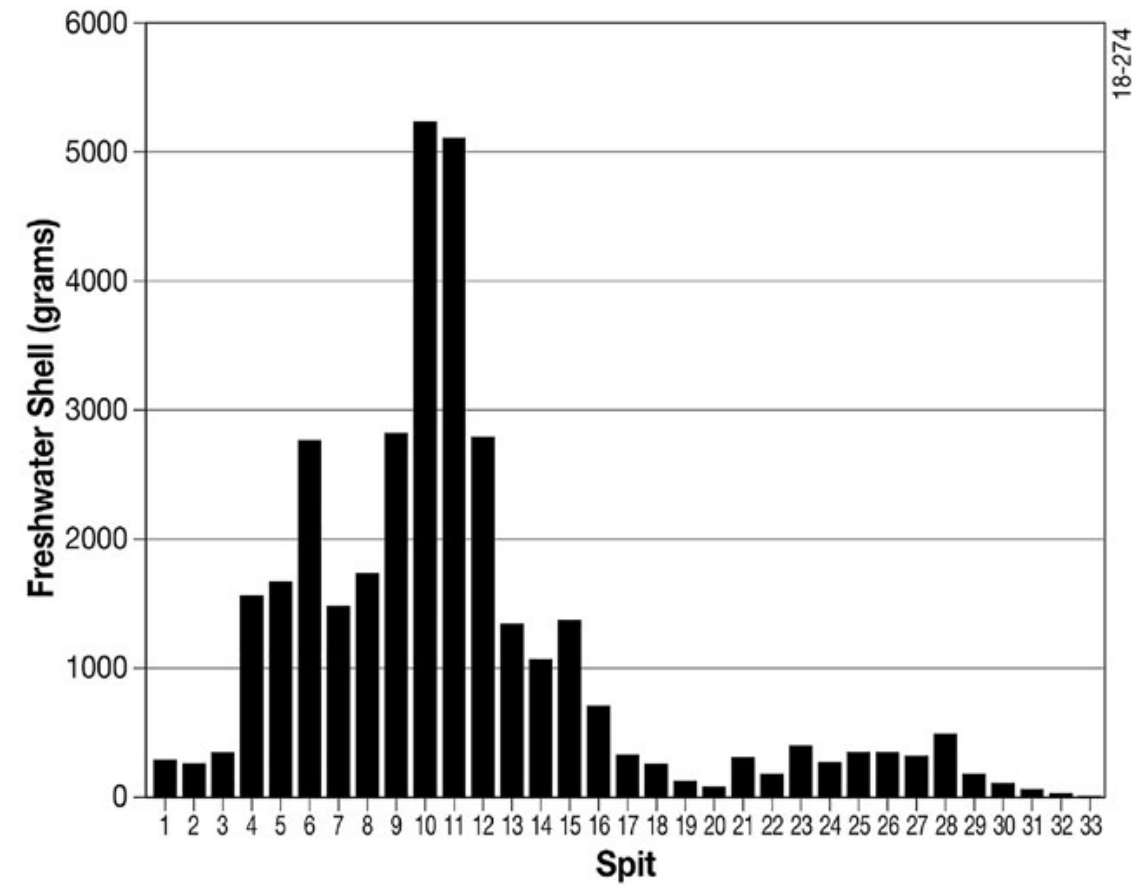

Figure 9.15: Gua Mo'o hono freshwater shell (weight shown by spit).

Source: Authors' data.

A component of the recovered shell was heavily burnt, making identification to species difficult. Shell quantities decreased with depth in layers where the bone appeared heavily burnt and some of the shell associated with presumed hearths contained fragments of burnt shell. The process of burning is likely to be incidental rather than from cooking the gastropods as the shell is so heavily burnt that the process has clearly been destructive. Most of the shell exhibits broken or fractured apices. This pattern may be the result of detaching the apex to extract the meat for consumption.

Two species were identified as dominating the samples (99.9\%). Both of these species probably occur in pools in the river adjacent to the site. One is a species of Tylomelania (Tylomelania sp.). There are both smooth- and ribbed-shelled specimens in this variable species (Thomas von Rintelen, pers. comm., 2014). The other species is Melanoides tuberculata. This species is less abundant than Tylomelania; however, it was not possible to completely separate the two species as Melanoides specimens can be confused with smaller specimens of Tylomelania if the shells are incomplete, as many in the deposit are (Thomas von Rintelen, pers. comm., 2014).

\section{Vertebrate fauna}

The bone assemblage was analysed at the Department of Archaeology and Natural History, The Australian National University, Canberra, between May and July 2013, and has since been returned to Balai Arkeologi Makassar, Makassar, where it has been curated for long-term preservation. The thorough recovery strategy that included sieving sediments through $1.5 \mathrm{~mm}$ mesh has resulted in the recovery and analysis of approximately 70,000 animal bones at Gua Mo'o 
hono, weighing almost $16 \mathrm{~kg}$ (Figure 9.16). The majority of these (over 98\%) consisted of very small fragments of bone measuring less than $20 \mathrm{~mm}$ in length. The very small size of most bone fragments has strongly influenced the numbers of identifiable bones recorded in the assemblage with just $1.5 \%$ of the total assemblage (Number of Individual Specimens, NISP $=1223$ ) identifiable to class or lower taxonomic level (Table 9.11). The rest were determined as ungulates $(\mathrm{n}=76)$ or intermediate/large mammals $(\mathrm{n}=29)$, and other small and unidentified vertebrates $(\mathrm{n}=28)$, while approximately 68,000 were categorised as indeterminate small fragments of animal bone.

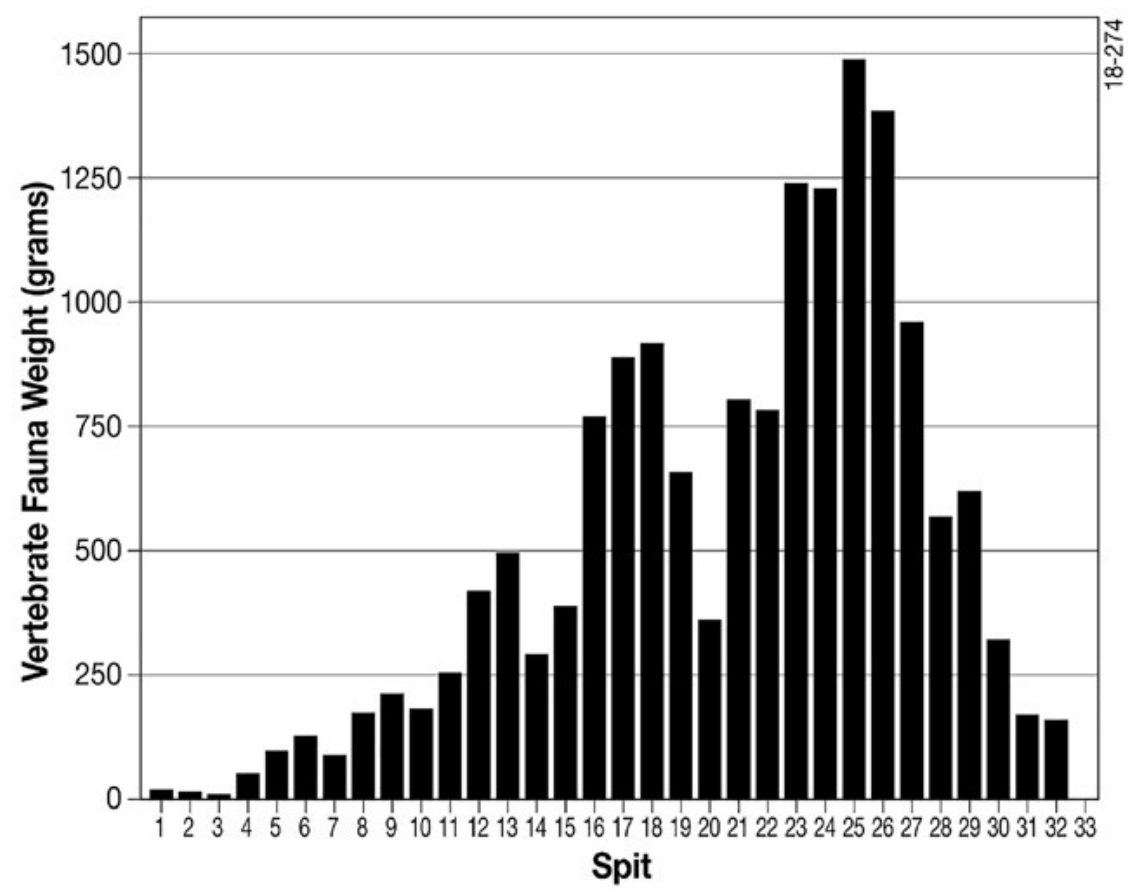

Figure 9.16: Gua Mo'o hono vertebrate fauna (weight shown by spit).

Source: Philip Piper's laboratory data.

Within the upper $80 \mathrm{~cm}$ (Spits 1-8, last c. 2000 years), bone fragments were typically light to dark brown in colour as a consequence of uptake of pigmentation from the surrounding dark soil matrices. Below this, there was an increased density of bone fragments, with increasing numbers of charred dark red/black (burnt) and blue/white-coloured (calcined) bones resulting from their exposure to heat at varying temperatures (see Lyman 1994). Below Spit 14, many bone fragments had been moderately or severely eroded, resulting in partial or complete loss of distinctive morphology. In the lower levels of excavation, in particular from Spit 27 down, only small burnt fragments of bone and teeth were recovered. This implies differential preservation of burnt and calcined bone fragments with depth at Gua Mo'o hono. Other common modifications that indicate some of the complex taphonomic processes involved in the preservation and destruction of bone on the site included longitudinal hairline surface cracking resulting from subsurface exposure to weathering prior to 'deep' burial, and rounding, polishing and loss of morphology. These latter types of modification are characteristic of bones either being transported by water, or by sediments suspended in flowing water passing over them and eroding surfaces (Behrensmeyer et al. 2000).

Butchery was rare in the highly fragmented and modified bone assemblage but evidence of extensive burning and the presence of shell and stone artefacts throughout, coupled with the degree of incidental burning on site indicate that people were the primary accumulators of the majority of large mammal remains. This interpretation is strengthened by the absence 
of any other large bone accumulators and/or scavengers on Sulawesi until the late Holocene introduction of the dog and Sunda porcupine (Hystrix javanica), and the lack of traces of gnawing on the fragments. The processes of accumulation of small vertebrate remains is a little more enigmatic; they could have resulted through natural accumulations of inhabitants of the rockshelter (bats), introduction of denizens of the local environment from in and around Gua Mo'o hono (mammals, reptiles and birds) by predators (e.g. Sulawesi civet cat), and/or human predation. The high proportion of murids within the late Holocene sequences might indicate a higher input of bones through natural processes of accumulation than in the mid-Holocene, where proportionately more large game was identified (Table 9.11).

Table 9.11: A provisional list of the different taxa identified in the zooarchaeological record of Gua Mo'o hono.

\begin{tabular}{|c|c|c|c|c|c|c|c|c|}
\hline Class & Order & Family & Taxon & $\begin{array}{l}\text { English } \\
\text { Vernacular }\end{array}$ & $\begin{array}{l}\text { Mid- } \\
\text { Holocene }\end{array}$ & \begin{tabular}{|l|} 
Later \\
Holocene
\end{tabular} & $\begin{array}{l}\text { Last c. } \\
2000 \\
\text { years }\end{array}$ & Total \\
\hline \multirow[t]{2}{*}{ Osteichthyes } & Anguilliformes & Anguillidae & & Eels & & & 4 & 4 \\
\hline & & & & Bony fishes & & 4 & 18 & 22 \\
\hline Amphibia & Aпuгa & & & Frogs and toads & 20 & 12 & 10 & 42 \\
\hline \multirow[t]{4}{*}{ Reptilia } & Squamata & Gekkonidae & & Geckos & 1 & 1 & & 2 \\
\hline & & Varanidae & Varanus sp(p). & Monitor lizards & 5 & 3 & 3 & 11 \\
\hline & $\begin{array}{l}\text { Serpentes } \\
\text { (suborder) }\end{array}$ & Pythonidae & Python sp. & Python & & 1 & & 1 \\
\hline & & & & Snakes ${ }^{1}$ & 91 & 73 & 33 & 197 \\
\hline Aves & & & & $\begin{array}{l}\text { Unidentified } \\
\text { birds }\end{array}$ & & 2 & 12 & 14 \\
\hline \multirow[t]{14}{*}{ Mammalia } & Diprotodontia & Phalangeridae & Ailurops ursinus & $\begin{array}{l}\text { Sulawesi bear } \\
\text { cuscus }\end{array}$ & 5 & 2 & & 7 \\
\hline & & & $\begin{array}{l}\text { Strigocuscus } \\
\text { celebensis }\end{array}$ & $\begin{array}{l}\text { Sulawesi dwarf } \\
\text { cuscus }\end{array}$ & 4 & & & 4 \\
\hline & & & & $\begin{array}{l}\text { Sulawesi } \\
\text { marsupials² }\end{array}$ & 4 & 7 & 5 & 16 \\
\hline & $\begin{array}{l}\text { Megachiroptera } \\
\text { (suborder) }\end{array}$ & & & $\begin{array}{l}\text { Old world fruit } \\
\text { bats }\end{array}$ & & 4 & & 4 \\
\hline & $\begin{array}{l}\text { Microchiroptera } \\
\text { (suborder) }\end{array}$ & & & $\begin{array}{l}\text { Insectivorous } \\
\text { bats }\end{array}$ & & 4 & 1 & 5 \\
\hline & Chiroptera & & & $\begin{array}{l}\text { Unidentified } \\
\text { Bats }\end{array}$ & 1 & 2 & & 3 \\
\hline & Primates & Tarsiidae & Tarsius sp. & Tarsier & 1 & & & 1 \\
\hline & & Cercopithecidae & Macaca sp(p). & $\begin{array}{l}\text { Sulawesi } \\
\text { macaques }\end{array}$ & 31 & 13 & 2 & 46 \\
\hline & Rodentia & Muridae & $\begin{array}{l}\text { Rattus } \\
\text { hoffmanni }\end{array}$ & Hoffmann's rat & 4 & 3 & & 7 \\
\hline & & & Rattus facetus & $\begin{array}{l}\text { Elegant } \\
\text { xanthurus rat }\end{array}$ & & 1 & 1 & 2 \\
\hline & & & $\begin{array}{l}\text { Bunomys } \\
\text { chrysocomus }\end{array}$ & $\begin{array}{l}\text { Common } \\
\text { Bunomys } \\
\end{array}$ & & 1 & & 1 \\
\hline & & & $\begin{array}{l}\text { Bunomys } \\
\text { andrewsi }\end{array}$ & $\begin{array}{l}\text { Andrew's } \\
\text { Bunomys }\end{array}$ & & 3 & 1 & 4 \\
\hline & & & Bunomys sp. & $\begin{array}{l}\text { Bunomys } \\
\text { species }\end{array}$ & & 1 & & 1 \\
\hline & & & Lenomys meyeri & $\begin{array}{l}\text { Meyer's } \\
\text { Lenomys }\end{array}$ & 2 & & & 2 \\
\hline
\end{tabular}




\begin{tabular}{|c|c|c|c|c|c|c|c|c|}
\hline Class & Order & Family & Taxon & $\begin{array}{l}\text { English } \\
\text { Vernacular }\end{array}$ & $\begin{array}{l}\text { Mid- } \\
\text { Holocene }\end{array}$ & $\begin{array}{l}\text { Later } \\
\text { Holocene }\end{array}$ & $\begin{array}{l}\text { Last c. } \\
2000 \\
\text { years }\end{array}$ & Total \\
\hline & & & $\begin{array}{l}\text { Paruromys } \\
\text { dominator }\end{array}$ & $\begin{array}{l}\text { Giant Sulawesi } \\
\text { rat }\end{array}$ & 3 & 1 & & 4 \\
\hline & & & $\begin{array}{l}\text { Taeromys } \\
\text { celebensis }\end{array}$ & $\begin{array}{l}\text { Long-tailed } \\
\text { Taeromys }\end{array}$ & & 2 & & 2 \\
\hline & & & $\begin{array}{l}\text { Taeromys } \\
\text { punicans }\end{array}$ & $\begin{array}{l}\text { Sulawesi forest } \\
\text { rat }\end{array}$ & 1 & 1 & & 2 \\
\hline & & & $\begin{array}{l}\text { Maxomys } \\
\text { musschenbroekii }\end{array}$ & $\begin{array}{l}\text { Musschenbroek's } \\
\text { Sulawesi } \\
\text { Maxomys } \\
\end{array}$ & 2 & 2 & & 4 \\
\hline & & & $\begin{array}{l}\text { Maxomys } \\
\text { hellwaldii }\end{array}$ & $\begin{array}{l}\text { Hellwald's } \\
\text { Sulawesi } \\
\text { Maxomys }\end{array}$ & & 1 & & 1 \\
\hline & & & Muridae & $\begin{array}{l}\text { Rat-sized } \\
\text { muridss }\end{array}$ & 62 & 102 & 24 & 188 \\
\hline & & Sciuridae & & Squirrels & & & 1 & 1 \\
\hline & Carnivora & Viverridae & $\begin{array}{l}\text { Macrogalidia } \\
\text { musschenbroekii }\end{array}$ & $\begin{array}{l}\text { Sulawesi palm } \\
\text { civet }\end{array}$ & 2 & 1 & 1 & 4 \\
\hline & & & & $\begin{array}{l}\text { Unidentified } \\
\text { viverrid }\end{array}$ & & 1 & 1 & 2 \\
\hline & & & & $\begin{array}{l}\text { Unidentified } \\
\text { carnivore } \\
\end{array}$ & 1 & & & 1 \\
\hline & Artiodactyla & Suidae & $\begin{array}{l}\text { Babyrousa } \\
\text { celebensis }\end{array}$ & $\begin{array}{l}\text { Sulawesi } \\
\text { Babirusa } \\
\end{array}$ & 43 & 2 & 1 & 46 \\
\hline & & & $\begin{array}{l}\text { Sus cf. } \\
\text { celebensis }\end{array}$ & $\begin{array}{l}\text { Celebes warty } \\
\text { pig }\end{array}$ & 28 & 3 & 1 & 32 \\
\hline & & & Suidae & $\begin{array}{l}\text { Barbirusa/ } \\
\text { Celebes warty } \\
\text { pig }\end{array}$ & 363 & 95 & 22 & 480 \\
\hline & & $\begin{array}{l}\text { Cervidae/ } \\
\text { Bovinae }\end{array}$ & & $\begin{array}{l}\text { Undifferentiated } \\
\text { deer or cattle }\end{array}$ & 13 & 5 & & 18 \\
\hline & & Bovinae & $\begin{array}{l}\text { Bubalus cf. } \\
\text { depressicornis }\end{array}$ & Lowland Anoa & 29 & 12 & 2 & 43 \\
\hline & & & & TOTAL NISP & 716 & 365 & 143 & 1224 \\
\hline
\end{tabular}

1. Probably includes numerous specimens of python.

2. As yet undifferentiated into Ailurops ursinus (Sulawesi bear cuscus) and Strigocuscus celebensis (small Sulawesi cuscus).

3. Several species of rats are present but not yet fully studied-this includes Rattus hoffmanni (Hoffmann's rat) and R. xanthurus (yellow-tailed rat).

Source: Philip Piper's laboratory data.

By far the most common taxon represented in the zooarchaeological record from Gua Mo'o hono is Suidae (NISP = 561). Pigs are present throughout the archaeological sequence from the earliest phases to the subsurface levels. The endemic suid taxa, the babirusa (Babyrousa celebensis; NISP $=50)$ (Figure 9.17A) and the Celebes warty pig (Sus celebensis; NISP = 33) (Figure 9.17B) are present (easily separable on the shape and morphology of the canines and premolars). Provisional biometric analyses of the upper and lower molars suggest that these are the only two pig taxa represented. Notably we have found no firm evidence of the remains of any introduced domestic pigs (S. scrofa) in the site. 

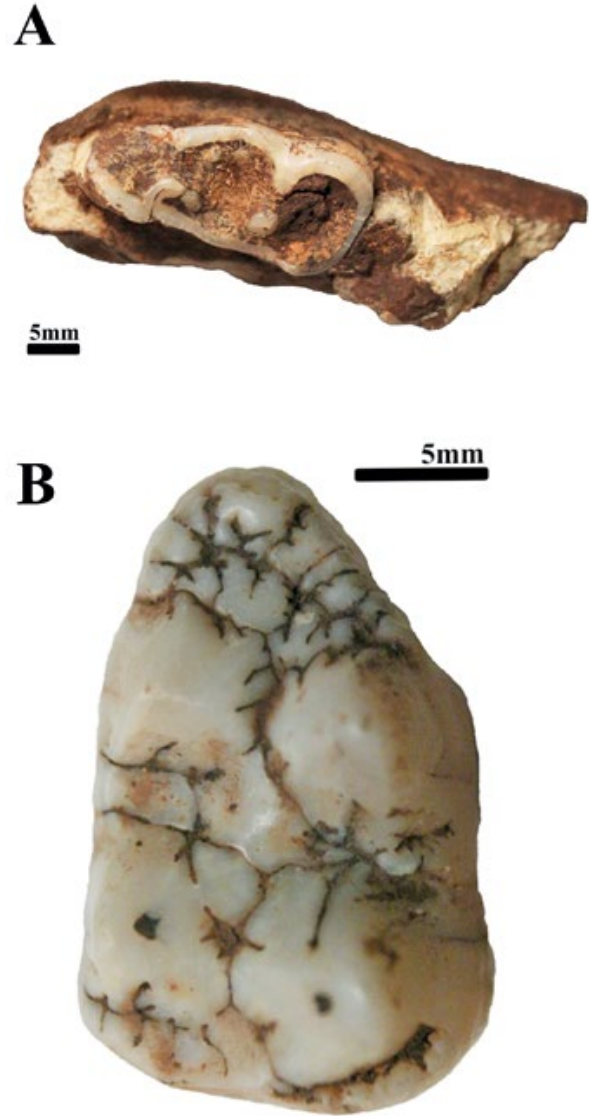

Figure 9.17: A - Babirusa (Babyrousa celebensis) right maxillary M3 from Spit 21; B - Fragment of Suidae right maxilla with broken $M 2$ and heavily worn M3 from Spit 18.

Source: Photographs by Philip Piper.

Another large endemic mammal, the Anoa (Bubalus depressicornis; NISP = 47), was recorded throughout the archaeological sequences in small numbers between Spits 4 and 30 , indicating the presence of the species in the local environments of Gua Mo'o hono through to the late Holocene (Table 9.11; Figure 9.18A). The remains of both the Sulawesi bear cuscus (Ailurops ursinus) and Sulawesi dwarf cuscus (Strigocuscus celebensis) (Figure 9.18B) have also been recorded from the mid (Spit 32) to the late Holocene (Spit 4). Forty-six Sulawesi macaque (Macaca $\mathrm{sp}(\mathrm{p})$.) remains, mostly teeth, were recorded in the assemblage. With reference to the known biogeographic distributions of the macaque species of Sulawesi, the likely candidates in the archaeological record of Gua Mo'o hono are the Tonkean macaque (Macaca tonkeana) and/or booted macaque ( $M$. ochreata ochreata) (Supriatna 2008; Supriatna and Richardson 2008). Six fragments, including four teeth of a civet cat (Viverridae) were also recorded. The maxillary right and left P4s from Spits 12 and 28 respectively, as well as the maxillary M1 from Spit 29 are all allocated to the brown palm civet (Macrogalidia musschenbroekii). This Sulawesi endemic has recently been recorded in the central and southeastern regions of the island at Rawa Aopa National Park, Tanjung Peropa Wildlife Reserve and Mangolo Recreation Forest (Tasirin et al. 2008). A maxillary canine from Spit 7 could potentially be from the endemic brown palm civet or the common palm civet (Paradoxurus hermaphroditus), a late Holocene introduction to Sulawesi (Heinsohn 2002).

Of the smaller mammals, a single right maxilla of a squirrel (Sciuridae) and several fragments of old world fruit bats (Megachiroptera) and insectivorous bats (Microchiroptera) were recorded throughout the archaeological sequences. But by far the most common small mammal skeletal elements were the cranial and postcranial elements of rats (Muridae; NISP $=203$ ). Guy Musser of the American Museum of Natural History kindly assisted identification. In total, 10 species of endemic rat have so far been recorded including the giant Sulawesi rat (Paruromys dominator; Figure 9.18D), Sulawesi forest rat (Taeromys punicans) and the elegant xanthurus rat (Rattus facetus). Research continues and the murids will be reported in greater detail elsewhere. In addition to mammals, numerous reptile skeletal elements were recorded. These included 215 snake vertebrae, many of which were likely to be from pythons, based on their large size. Also represented were several specimens of monitor lizard (Varanus $\mathrm{sp}(\mathrm{p})$.), two fragments of Gecko (Gekkonidae) premaxillae, 42 pieces of frog and/or toad and 14 fragments of unidentified bird bone. Fish vertebrae were recorded from the surface to Spit 12 , but the clear majority $(21 / 26(81 \%))$ were identified in the subsurface layers (Spit 1). These included the characteristic dentaries and ceratohyals of freshwater eels (Anguillidae). 


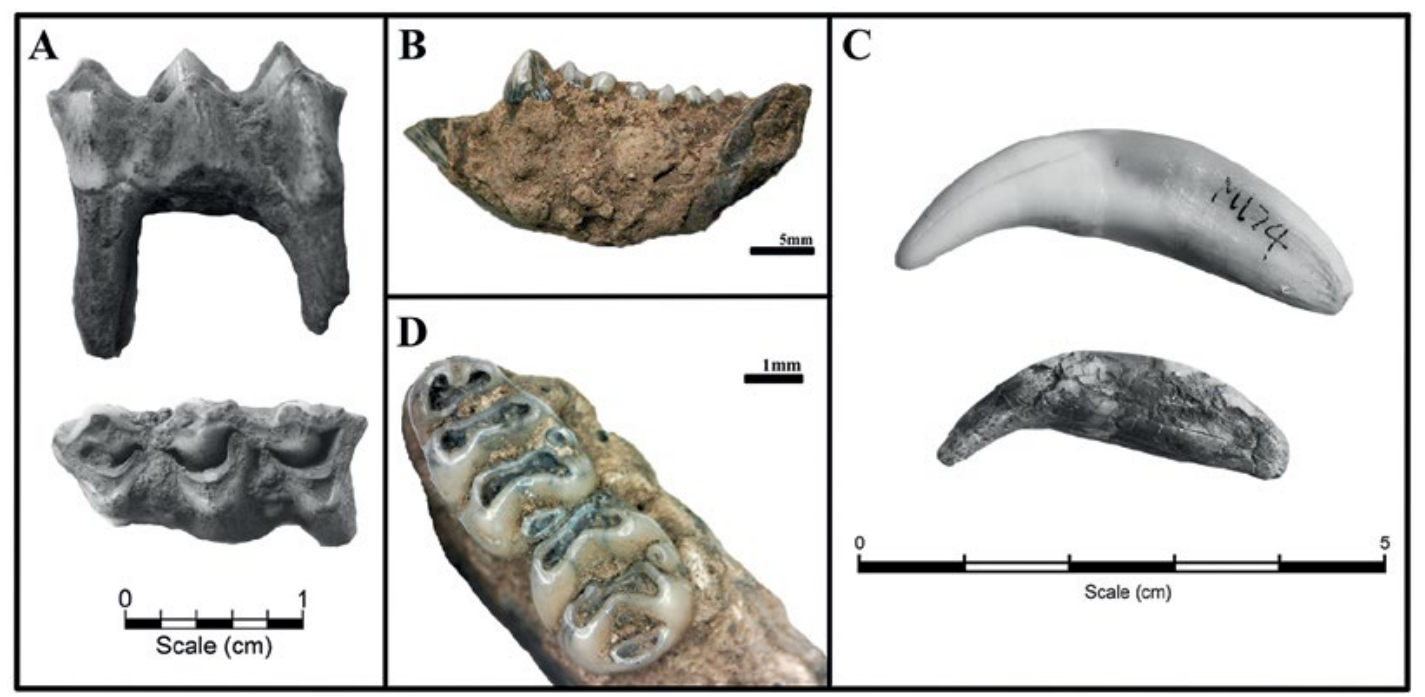

Figure 9.18: A - The labial (above) and occlusal (below) aspects of the left mandibular dp4 provisionally recorded as the Javan deer (Rusa timorensis) and subsequently reallocated to Anoa (Bubalus depressicornis). B - Strigocuscus celebensis left mandibular body from Spit 17. C - (below) The left mandibular canine from Spit 13 originally attributed to a dog and subsequently reallocated to the Sulawesi brown civet cat (Macrogalidia musschenbroekii). D - Fragment of giant Sulawesi rat (Paruromys dominator) right mandible with M1 and M2 from Spit 19.

Source: Photographs by Philip Piper.

During preliminary analysis, two species of terrestrial vertebrate introduced to Sulawesi were provisionally identified: the dog (Canis lupus familiaris) and deer (Rusa timorensis). Continued analysis and access to more comprehensive comparative collections of Sulawesi's endemic fauna and supporting biometric data have questioned both these identifications.

A single mandibular left canine recovered from Spit 13 was initially considered to be that of domestic dog (Figure 9.18C). A sample of dentine from the tooth returned a direct date of $3870 \pm 40$ BP (SANU-35532), calibrating to $4467-4274$ (84.5\%) or 4256-4208 (10.9\%) cal BP (Table 9.1). The stable isotope ratios are typical of a carnivore feeding on terrestrial resources and are considered reliable $\left(\delta^{13} \mathrm{C}-19.4 \% 0, \delta^{15} \mathrm{~N}-8.7 \% 0\right)$. The direct date is supported by two charcoal samples: one from Spit 13 dated 3820-3571 cal BP (D-AMS 001623) and another from the underlying Spit 15 of 4405-4093 cal BP (D-AMS 001624b) (Table 9.1). The evidence clearly indicates that the canine was from an animal present on the island in the mid to late 5 th millennium BP. If correctly identified, this would have represented the oldest securely dated introduction for domestic dog anywhere in ISEA. However, closer morphometric examination of maxillary and mandibular canines of the endemic brown palm civet indicates that they are considerably larger than expected for a moderately sized civet cat, and overlap in size with small Southeast Asian dogs. Although the maxillary canines can be easily differentiated between dogs and brown civet on morphology, the mandibular canines are considerably more difficult to distinguish. To increase confidence in species identification, the specimen was sent to the ancient DNA laboratory at the University of Oxford for sequencing. Unfortunately, the analysis proved inconclusive. Further suspicion was raised when an opportunity arose to study the much better preserved bone assemblage from the rockshelter site of Gua Talimbue, just a short distance from Gua Mo'o hono. Here, several well-preserved examples of brown palm civet were identified, including maxillary and mandibular canines. Thus, the Gua Mo'o hono canine is in all likelihood from the brown palm civet, rather than a dog. 
Two teeth, a left mandibular dp4 from Spit 4 and a molar fragment from Spit 9 were tentatively identified as Javan deer (Rusa timorensis). Comparative analysis highlighted the problem of differentiating some skeletal and dental elements of introduced deer from the endemic Anoa (Bubalus depressicornis). This was particularly evident in the maxillary and mandibular dp $4 \mathrm{~s}$, which look remarkably like deer maxillary M1s and mandibular dp4s (Figure 9.18A). The specimens have been subsequently reallocated as the left mandibular dp4 and molar/dp4 fragment of Anoa. The only directly radiometrically dated bone identified as deer is a terminal phalanx from Minanga Sipakko that returned an age of 2810 \pm 50 BP or 2789-3059 cal BP (OZE 132) (Bulbeck and Nasruddin 2002). A recent study of c. 2800 bone fragments recovered during the 2004 and 2007 excavations at Minanga Sipakko found just three Anoa teeth (including one confusing maxillary dp4) and no Javan deer skeletal elements (Piper and Campos, unpublished data). Thus, the identification of a single Javan deer basal phalange from Minanga Sipakko should be treated with some caution. Simons and Bulbeck (2004) also noted two fragments of deer previously recorded from Leang Balisao in the Southwest Sulawesi highlands, while Simons (1997) identified six from Leang Karassak and one or two pieces from Leang Burung 1 in the Maros karsts. None of the actual identified specimens are reported. From these results and associated radiocarbon dates, Simons and Bulbeck (2004) argued that the deer was likely introduced to Sulawesi by c. 4000 BP. Although a $4000 \mathrm{BP}$ introduction of deer to Sulawesi is certainly possible, direct dates on clearly identified deer bones/teeth are required to confirm the antiquity for the translocation of this large ungulate from the Sundaic biogeographic region to Sulawesi.

These two examples illustrate the difficulty the analyst often faces when attempting to differentiate between related taxa in the zooarchaeological record, especially in the absence of sufficient comparative collections. Confidence in distinguishing between taxa becomes all that more important when making critical identifications, particularly if the appearance of a domestic or translocated animal in a region where it was previously absent has significant implications for our understanding of human behaviour.

The faunal record from Gua Mo'o hono indicates that humans have been active in and around the rockshelter since at least $6500 \mathrm{cal} \mathrm{BP}$. They primarily hunted babirusa and the Celebes warty pig, and to a lesser extent the Anoa. A variety of other intermediate and small vertebrates were likely captured using a variety of hunting technologies such as traps that would have been effective against nocturnal and diurnal carnivorous and omnivorous mammals and reptiles like the brown palm civet, Sulawesi endemic macaques and monitor lizard. A study of the osseous technologies from Walandawe sites has also indicated that composite projectile technologies might also have been present from the early Holocene onwards (Aplin et al. 2016). The habitat preferences of taxa recorded at Gua Mo'o hono (Burton and Macdonald 2008; Salas et al. 2008) suggest that the occupants foraged within a variety of environments that included dense moist tropical rainforest, along rivers banks, in swamp forest and in more open woodland. Based on the state of preservation of the bone, the concentration of most of the fish (including eel) and bird bones within the uppermost spits is probably a result of preservation bias, rather than reflecting a distinctive change in human subsistence behaviour. From the terminal Pleistocene onwards across Southeast Asia as far east as Palawan (Piper et al. 2011) and Sulawesi (Simons and Bulbeck 2004), a similar focus on the capture of larger mammals (including pigs and primates) was a widespread component of diverse foraging strategies that included the hunting and trapping of a variety of small mammals and reptiles (Piper and Rabett 2009; Barker and Rabett 2010; Rabett et al. 2013). Community participation in foraging and the setting and maintenance of traps was probably one method of offsetting risk from failed large game hunts (Piper and Rabett 2014), as well as adding diversity to the diet. 
The bone assemblage for the last c. 2000 years is relatively small, with a total number of fragments of 1715 , compared with c. 10,000 and c. 67,000 for the mid and late Holocene, respectively. This has resulted in only 142 taxonomic identifications in the most recent deposits compared with 1081 in earlier phases (Table 9.11). While this may explain the limited taxonomic diversity of the assemblage postdating c. $2000 \mathrm{cal} \mathrm{BP}$, it is notable that many of the obligatory forest dwelling rats (Taeromys spp. and Paruromys dominator) are absent. The only two identified rat species within this late sequence are the elegant xanthurus rat (Rattus facetus) and Andrew's Bunomys (Bunomys andrewsi), with the latter known to tolerate disturbance and vegetation modification (Ruedas and Musser 2008). This might tentatively indicate some substantial human modifications to the local environment around Gua Mo'o hono in the latter phases of human frequentation of the rockshelter, even though there is no clear evidence for the introduction of domestic pig or dog.

Several translocated wild animals common in Sulawesi today are also absent from the archaeological record of Gua Mo'o hono, and the timing of their introductions remains enigmatic across the island. This includes the Javan deer (discussed above), common palm civet (Paradoxurus hermaphroditus), Malayan civet (Viverra tangalunga) and Sunda porcupine (Hystrix javanica) (Heinsohn 2002). The common palm civet has been tentatively recorded at Liang Bua on Flores at c. $4000 \mathrm{BP}$ (van den Bergh et al. 2009), and directly dated at Matja Kuru 1 in Timor Leste to $2741 \pm 27$ BP (Wk-31508; O'Connor 2015). There is currently no confirmed archaeological record of this species on Sulawesi. The recovery of well-stratified and directly dated specimens that have been confidently identified as an introduced species is required before we can clarify the timing of arrival of these invasives.

\section{Bone artefacts}

After allowing for fragments from the same original artefact, a total of 49 osseous artefacts were identified from Gua Mo'o hono, distributed though the deposit as follows: c. 6000 to $7000 \mathrm{cal} \mathrm{BP}(\mathrm{n}=24), 4500$ to $6000 \mathrm{cal} \mathrm{BP}(\mathrm{n}=3), 3400$ to $4500 \mathrm{cal} \mathrm{BP}(\mathrm{n}=8)$, and $<3400 \mathrm{cal}$ $\mathrm{BP}(\mathrm{n}=14)$.

The majority of the osseous artefacts can be classified as bone points or point fragments and are made from cortical bone. An example is the attenuate bone point from Spit 7, which shows longitudinal striations from scraping to produce the point and small transverse striations near the midpoint, possibly produced during hafting wear by sand grains trapped in the binding (Figure 9.19A). Points made on dentine are also represented (Figures 9.19B and 9.19D). One unusual example is made on a babirusa mandibular incisor from Spit 28 (Figure 9.19D). It shows sub-parallel transverse and oblique striations, which are most pronounced on the enamel near the tip. This point in unique in terms the assemblage recovered from the Walandawe excavations as it retains the enamel crown, allowing its identification to taxon. Aplin et al. (2016) note that while several of the dentine points are likely suid incisors, none of those examined for that study retained the enamel crown. ${ }^{3}$

3 The bone point in Gua Mo'o hono made on a babirusa mandibular incisor from Spit 28 was found amongst the faunal assemblage after that study was completed. 


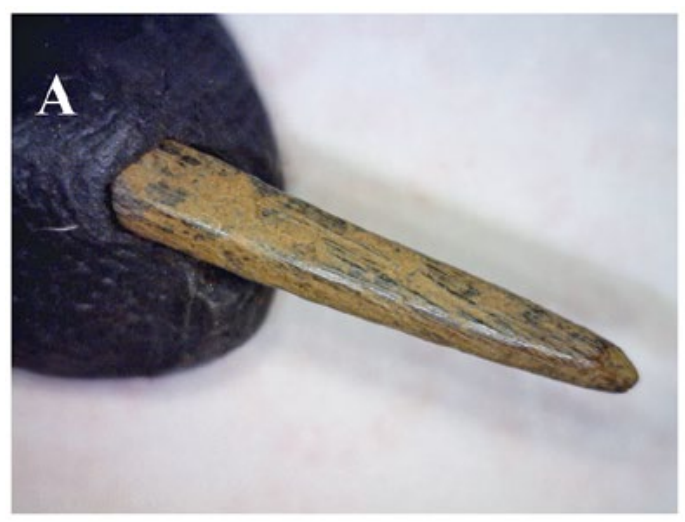

\section{B}

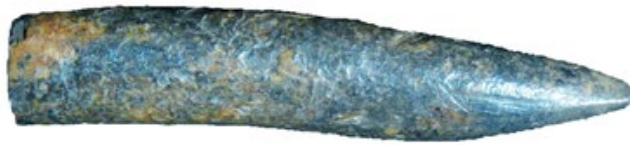

$5 \mathrm{~mm}$
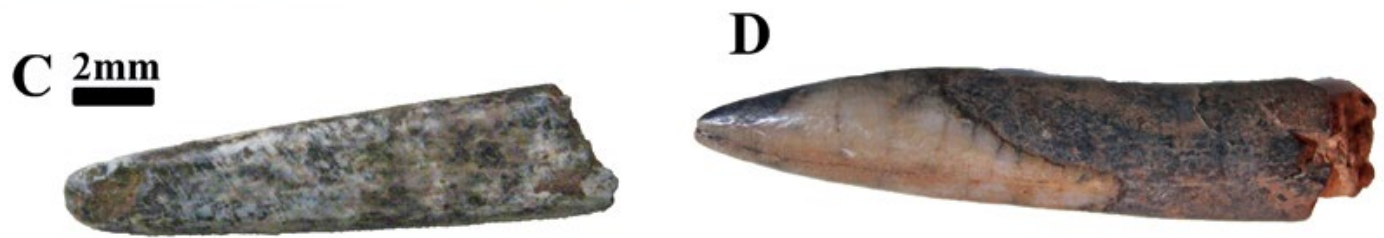

$5 \mathrm{~mm}$

Figure 9.19: A - Attenuate bone unipoint from Gua Mo'o hono Spit 7 made on cortical bone showing longitudinal striations from scraping during manufacture and small parallel transverse striations near the midpoint, which may be from hafting wear. B - Bone point probably made on suid incisor from Spit 24. C - Incidentally calcined bone point made on cortex bone from Gua Mo'o hono Spit 25. D - Bone point made on babirusa mandibular incisor from Gua Mo'o hono Spit 28.

Source: Photographs by Sue $0^{\prime}$ Connor.

Many are merely fragments and it is difficult to be certain if they are from unipoints or bipoints. Many of the artefacts are also burnt, including some examples burnt to the point of calcination (Figure 9.19C). The calcined artefacts are thought to have been burnt incidentally subsequent to discard, as extreme calcination renders bone very brittle and unsuitable for tool manufacture or use.

One notable expedient bone artefact is a tusk tool from Spit 11 (Aplin et al. 2016), probably dating to c. $3500 \mathrm{cal}$ BP. It is formed from the terminal section of a babirusa lower canine. The basal end is roughly fractured and shows no other modification. The tip is essentially unmodified except through use and some probable resharpening (Figure 9.20A). The Gua Mo'o hono tusk tool was clearly used for cutting. The outer enamel surface has a high gloss and fine oblique striations that are sub-parallel along most of the preserved length. The cutting edge is rounded from use, and relatively blunt except where it has been resharpened (Figures 9.20C and 9.20D). The tip area of the artefact has some bilateral spalling. External spalling is concentrated on the chisel-like end of the tool (Figure 9.20E). It was probably produced in an attempt to resharpen the cutting edge, which may have broken the artefact. Internal spalling on the tip of the artefact is more extensive and extends not only around the tip but back along the blade for c. $10 \mathrm{~mm}$ (Figure 9.20F). We suspect the original use was systematic and repetitive, and may have involved the cutting of a plant material that contained siliceous phytoliths. Perhaps due to the blunting of the natural cutting edge of the tooth, spalls were struck from one side and then the other to allow continued use of the artefact, albeit most likely in a different fashion with more focus on the tip than on the cutting edge (Aplin et al. 2016). 


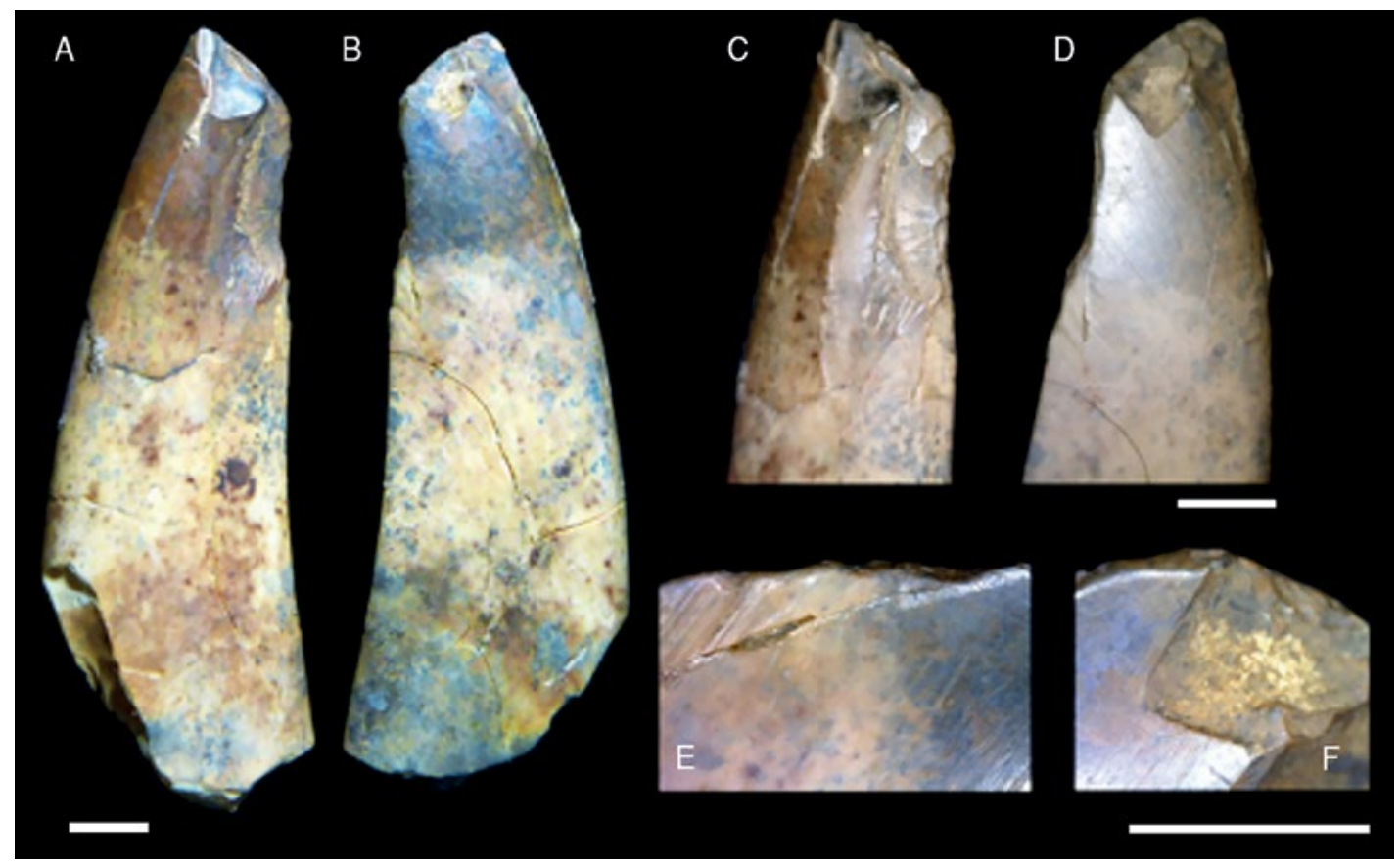

Figure 9.20: Tusk tool from Gua Mo'o hono Spit 11.

Source: Photograph by sue $0^{\prime}$ Connor.

Four fragments of burnt cortex bone from the upper late Holocene levels of Gua Mo'o hono (Spits 4 and 5) probably represent pieces of a single original artefact manufactured from a longbone shaft fragment of a large mammal. On each fragment, the outer surface of the bone has at least one flat, glossy facet. The striations on these facets are very fine, suggesting they were ground on a very fine-grained stone. While the original form is uncertain, one fragment $25 \mathrm{~mm}$ in length has a narrow grinding facet on the external surface as well as a second facet that descends to what might have been a bevelled tip. If this interpretation is correct, this singular artefact may have originally resembled some of the potential wood-working tools from Pulau Balambangan and other sites categorised by Rabett (2005) as 'edge tools'.

\section{Discussion and conclusion}

The Gua Mo'o hono sequence demonstrates that humans were active in and around the rockshelter from at least $6500 \mathrm{cal} \mathrm{BP}$ and informs on early to late Holocene subsistence and technology in Southeast Sulawesi. Spits 17 to 32 reflect a period of intensive habitation with high discard rates of flaked stone artefacts during the early 7 th millennium BP. Local nodules of high-quality chert were flaked to produce cores, which in turn were extensively reduced in the production of flakes. Only a small proportion of the flakes were retouched, with many of the most extensively retouched pieces being small and steep-angled. These steeply retouched pieces are likely to have functioned as scrapers for a variety of woodworking tasks. Notably, the Maros points and microliths of the Toalean are absent from the assemblage. This non-Toalean tool technology evidently persisted until later times, although associated with lower rates of artefact discard above Spit 8, roughly coinciding with the first appearance of pottery. This is no doubt due to changes in settlement and subsistence following the late movement of agricultural communities into the region and the availability of metal tools (Bulbeck et al. 2016). Bone tools were utilised throughout the sequence and include bone bipoints, unipoints and expedient tools such as the tusk tool that was used for cutting. Small clusters of oblique to transverse 
striations on the mid-section of the bone tools in the larger Walandawe bone artefact collection are possibly caused by the motion of sediment grains trapped in cordage. In combination with specific crushing and breakage patterns, this suggests that some implements might have been hafted as projectile points for use in hunting (Aplin et al. 2016).

The zooarchaeological record from Gua Mo'o hono provides insights into mid to late Holocene foraging strategies in the north of the southeastern peninsula of Sulawesi. It indicates that, along with encounter hunting, the occupants probably employed a range of techniques to capture a variety of mammal and reptile taxa from a diversity of terrestrial and arboreal habitats within tropical rainforest and swamp forest environments. However, there appears to have been a particular focus on suids, both the babirusa and the Sulawesi warty pig, which might have been common close to the rockshelter during its occupation. Notably, however, there is no evidence for the consumption of the introduced pig Sus scrofa, or even the presence of dog in Gua Mo'o hono. Pig and dog have both been identified in West Sulawesi along the Karama River at sites such as Minanga Sipakko and Kamassi, where communities established open-air settlements by c. 3500 cal BP. These settlements also differ from Gua Mo'o hono in that they are often considered to represent colonisation of the island by Malayo-Polynesian-speaking populations and exhibit a variety of associated material culture such as red-slipped pottery, ground-stone technology and stone beads (Anggraeni et al. 2014). Similar types of artefacts are effectively absent from Gua Mo'o hono.

The late appearance of pottery at Gua Mo'o hono also suggests that the inland expansion of agriculturally based populations was a long and drawn-out process, as proposed by Simons and Bulbeck (2004). It not yet possible to determine whether the pottery in Gua Mo'o hono was used by indigenous foragers who had acquired cooking and other vessels from local immigrant farming populations and continued to frequent the site, or whether the shelter was simply utilised on an occasional basis by, say, hunting parties from local villages established nearby. Simons (1997) proposed that late occupation of rockshelters in Southwestern Sulawesi involved indigenous hunter-gatherers who, in the late Holocene, began to engage with the farmers they encountered. A similar argument has been applied to Luzon in the Philippines, where the earliest settled populations introduced a variety of material cultural items, many similar to those recorded along the Karama valley, identified at Dimolit (Peterson 1974) and along the Cagayan River at sites such as Nagsabaran (Hung et al. 2011) and other Lal-lo shell middens (Mijares 2007). Mijares (2007) argued that cave sites within the Peñablanca region of northern Luzon, close to the Cagayan River valley, continued to be frequented by foragers long after the establishment of the first sedentary settlements in lowland valleys. The hunter-gatherers maintained their traditional existence, trading for pottery but little else of the new material culture brought by Neolithic immigrants. On balance, the overall decline in occupational evidence in the upper levels of Gua Mo'o hono shelter might seem to favour the hypothesis of only occasional short-term and/or opportunistic use of the shelter by sedentary populations while exploiting the surrounding forests and nearby river.

\section{Author biographies}

Sue O’Connor Department of Archaeology and Natural History, School of Culture, History and Language, College of Asia and the Pacific, The Australian National University, Canberra, Australia; and ARC Centre of Excellence for Australian Biodiversity and Heritage, The Australian National University, Canberra, Australia

David Bulbeck Department of Archaeology and Natural History, School of Culture, History and Language, College of Asia and the Pacific, The Australian National University, Canberra, Australia 
Philip J. Piper School of Archaeology and Anthropology, College of Arts and Social Sciences, The Australian National University, Canberra, Australia

Fadhila Aziz Department of Prehistory, Research and Development Agency, Ministry of Education and Culture, National Research Centre of Archaeology, Jakarta, Indonesia

Ben Marwick Department of Anthropology, University of Washington, Seattle, USA

Fredeliza Campos School of Archaeology and Anthropology, College of Arts and Social Sciences, The Australian National University, Canberra, Australia

Jack Fenner Department of Archaeology and Natural History, School of Culture, History and Language, College of Asia and the Pacific, The Australian National University, Canberra, Australia

Ken Aplin Department of Archaeology and Natural History, School of Culture, History and Language, College of Asia and the Pacific, The Australian National University, Canberra, Australia

Fakhri Makassar Archaeology Office, Makassar, South Sulawesi, Indonesia

Suryatman Makassar Archaeology Office, Makassar, South Sulawesi, Indonesia

Tim Maloney Department of Archaeology and Natural History, School of Culture, History and Language, College of Asia and the Pacific, The Australian National University, Canberra, Australia

Budianto Hakim Makassar Archaeology Office, Makassar, South Sulawesi, Indonesia

Rachel Wood Research School of Earth Sciences, The Australian National University, Canberra, Australia

\section{References}

Anggraeni, T. Simanjuntak, P. Bellwood and P. Piper. 2014. Neolithic foundations in the Karama valley, West Sulawesi, Indonesia. Antiquity 88(341):740-756. doi.org/10.1007/978-94-024-0899-7_13 (accessed 5 June 2018).

Aplin, K.P., S. O’Connor, D. Bulbeck, P.J. Piper, B. Marwick, E.S. Pierre and F. Aziz. 2016. The Walandawe tradition from Southeast Sulawesi and osseous artefact traditions in Island Southeast Asia. In M. Langley (ed.), Osseous Projectile Technology: Towards an Understanding of Pleistocene Cultural Variability. Vertebrate Paleobiology and Paleoanthropology Series. Dordrecht: Springer. doi.org/ 10.1007/978-94-024-0899-7_13 (accessed 5 June 2018).

Aubert, M., A. Brumm, M. Ramli, T. Sutikna, E.W. Saptomo, B. Hakim, M.J. Morwood, G.D. van den Bergh, L. Kinsley and A. Dosseto. 2014. Pleistocene cave art from Sulawesi, Indonesia. Nature 514(7521):223-227. doi.org/10.1038/nature13422 (accessed 5 June 2018).

Barker, G. and R.J. Rabett. 2010. Late Pleistocene and early Holocene forager mobility in Southeast Asia. In B. Bellina, E.A. Bacus, T.O. Pryce and J.W. Christie (eds), 50 Years of Archaeology in Southeast Asia: Essays in Honour of Ian Glover, pp. 66-77. Bangkok: River Books.

Behrensmeyer, A.K., S.M. Kidwell and R.A. Gastaldo. 2000. Taphonomy and paleobiology. Paleobiology 26(sp4):103-147. doi.org/10.1666/0094-8373(2000)26[103:TAP]2.0.CO;2 (accessed 5 June 2018).

Bräuer, G. 1988. Osteometrie des Kranialskeletts. In R. Knußman (ed.), Wesen und Methoden der Anthropologie, 1. Teil, Wissenschafttheorie, Geschichte, Morphologischen Methoden. Stuttgart: Gustav Fischer Verlag. 
Bronk Ramsey, C., T.F.G. Higham, F. Brock, D. Baker and P. Ditchfield. 2009. Radiocarbon dates from the Oxford AMS System: Archaeometry Datelist 33. Archaeometry 51(2):323-349. doi.org/10.1111/ j.1475-4754.2008.00457.x (accessed 5 June 2018).

Brown, P. 1989. Coobool Creek. Terra Australis 13. Canberra: The Australian National University.

Bulbeck, D. 2004. Divided in space, united in time: The Holocene prehistory of South Sulawesi. In S.G. Keates and J.M. Pasveer (eds), Quaternary Research in Indonesia, pp. 129-166. Modern Quaternary Research in Southeast Asia, Volume 18. Leiden: A.A. Balkema.

Bulbeck, D. 2004. South Sulawesi in the corridor of island populations along East Asia's Pacific rim. In S. Keates and J.M. Pasveer (eds), Quaternary Research in Indonesia, pp. 221-258. Modern Quaternary Research in Southeast, Volume 18. Leiden: A.A. Balkema.

Bulbeck, D., F.A. Aziz, S. O’Connor, A. Calo, J.N. Fenner, B. Marwick, J. Feathers, R. Wood and D. Prastiningtyas. 2016. Mortuary caves and the dammar trade in the Towuti-Routa region, Sulawesi, in an Island Southeast Asian context. Asian Perspectives 55(2):148-183. doi.org/10.1353/asi.2016.0017 (accessed 5 June 2018).

Bulbeck, D. and Nasruddin. 2002. Recent insights into the chronology and ceramics of the Kalumpang site complex, South Sulawesi, Indonesia. Bulletin of The Indo-Pacific Prehistory Association 22:83-99.

Bulbeck, D., M. Pasqua and A. Di Lello. 2000. Culture history of the Toalean of south Sulawesi, Indonesia. Asian Perspectives 39(1-2):71-108. doi.org/10.1353/asi.2000.0004 (accessed 5 June 2018).

Burton, J. and A.A. Macdonald. 2008. Sus celebensis. The IUCN Red List of Threatened Species. www. iucnredlist.org/details/41773/0 (accessed 11 August 2014).

Glover, I.C. and G. Presland. 1985. Microliths in Indonesian flaked stone industries. In V.N. Misra and P. Bellwood (eds), Recent Advances in Indo-Pacific Prehistory, pp. 185-195. Leiden: E.J. Brill.

Heinsohn, T. 2002. Animal translocation: Long-term human influences on the vertebrate zoogeography of Australasia (natural dispersal versus ethnophoresy). Australian Zoologist 32(3):351-376. doi.org/ 10.7882/AZ.2002.014 (accessed 5 June 2018).

Hillson, S. 1996. Dental Anthropology. Cambridge: Cambridge University Press. doi.org/10.1017/CBO 9781139170697 (accessed 5 June 2018).

Hiscock, P. 2015. Making it small in the Palaeolithic: Bipolar stone-working, miniature artefacts and models of core recycling. World Archaeology 47(1):158-169. doi.org/10.1080/00438243.2014.991808 (accessed 5 June 2018).

Hogg, A.G., Q. Hua, P. Blackwell, M. Niu, C. Buck, T. Guilderson, T. Heaton, J. Palmer, P. Reimer, R. Reimer, C. Turney and S. Zimmerman. 2013. SHCal13 Southern Hemisphere calibration, 0-50,000 years cal BP. Radiocarbon 55(4):1889-1903. doi.org/10.2458/azu_js_rc.55.16783.

Hung, H.-c., M.T. Carson, P. Bellwood, F.Z. Campos, P.J. Piper, E. Dizon, M.J.L.A. Bolunia, M. Oxenham and Z. Chi. 2011. The first settlement of Remote Oceania: The Philippines to the Marianas. Antiquity 85(329):909-926.

Larnach, S.L. and N.W.G. Macintosh. 1971. The Mandible in Eastern Australian Aborigines. Oceania Monographs 17. Sydney: University of Sydney.

Lyman, R.L. 1994. Vertebrate Taphonomy. Cambridge: Cambridge University Press. doi.org/10.1017/ CBO9781139878302 (accessed 5 June 2018).

McWilliam, A. and S. Lorenzen. 2009. Sulawesi Nickel Baseline and Community Relations Project. Canberra: The Australian National University. 
Mijares, A.S.B. 2007. Unearthing Prehistory: The Archaeology of Northeastern Luzon, Philippine Islands. BAR International Series 1613. Oxford: John and Erica Hedges Ltd.

Moore, M.W., T. Sutikna, Jatmiko, M.J. Morwood and A. Brumm. 2009. Continuities in stone flaking technology at Liang Bua, Flores, Indonesia. Journal of Human Evolution 57(5):503-526. doi.org/ 10.1016/j.jhevol.2008.10.006 (accessed 5 June 2018).

Morant, G.M. 1923. A first study of the Tibetan skull. Biometrika 14(3/4):193-260. doi.org/10.2307/ 2331812.

O'Connor, S. 2015. Rethinking the Neolithic in island Southeast Asia, with particular reference to the archaeology of Timor-Leste and Sulawesi. Archipel 90:15-48. doi.org/10.4000/archipel.362 (accessed 5 June 2018).

Oktaviana, A.A., D. Bulbeck, S. O'Connor, B. Hakim, Suryatman, U.P. Wibowo, E. St Pierre and Fakhri. 2016. Hand stencils with and without narrowed fingers at two new rock art sites in Sulawesi, Indonesia. Rock Art Research 33(1):32-48.

Peterson, W. 1974. Summary report of two archaeological sites from north-eastern Luzon. Archaeology \& Physical Anthropology in Oceania 9(1):26-35.

Piper, P.J., J. Ochoa, E.C. Robles, H. Lewis and V. Paz. 2011. Palaeozoology of Palawan Island, Philippines. Quaternary International 233(2):142-158. doi.org/10.1016/j.quaint.2010.07.009 (accessed 5 June 2018).

Piper, P.J. and R.J. Rabett. 2009. Hunting in a tropical rainforest: Evidence from the Terminal Pleistocene at Lobang Hangus, Niah Caves, Sarawak. International Journal of Osteoarchaeology 19(4):551-565. doi.org/10.1002/oa.1046 (accessed 5 June 2018).

Piper, P.J. and R.J. Rabett. 2014. Late Pleistocene subsistence strategies in Southeast Asia and their implications for understanding the development of modern human behaviour. In R. Dennell and M. Porr (eds), Southern Asia, Australasia and the Search for Modern Human Origins, pp. 118-134. Cambridge: Cambridge University Press.

Rabett, R.J. 2005. The early exploitation of Southeast Asian mangroves: Bone technology from caves and open sites. Asian Perspectives 44(1):154-179. doi.org/10.1353/asi.2005.0013 (accessed 5 June 2018).

Rabett, R.J., G. Barker, H. Barton, C. Hunt, L. Lloyd-Smith, V. Paz, P. Piper, R. Premathilake, G. Rushworth, M. Stephens and K. Szabó. 2013. Landscape transformations and human responses c. 11,500-c. 4500 years ago. In G. Barker (ed.), Rainforest Foraging and Farming in Island Southeast Asia: the Archaeology of the Niah Caves, Sarawak: Volume 1, pp. 217-253. United Kingdom: McDonald Institute for Archaeological Research.

Ruedas, L. and G. Musser. 2008. Bunomys andrewsi. The IUCN Red List of Threatened Species. www.iucn redlist.org/details/3327/0 (accessed 11 August 2014).

Salas, L., C. Dickman, K. Helgen and T. Flannery. 2008. Ailurops ursinus. The IUCN Red List of Threatened Species. www.iucnredlist.org/details/40637/0 (accessed 11 August 2014).

Simons, A.G. 1997. The Whole Hog: The Indigenous Response to the Introduction of Farming to South Sulawesi: A Faunal Analysis. Unpublished BA (Hons) thesis, Centre for Prehistory, University of Western Australia, Perth.

Simons, A.G. and D. Bulbeck. 2004. Late Quaternary faunal successions in South Sulawesi, Indonesia. In S.G. Keates and J.M. Pasveer (eds), Quaternary Research in Indonesia Asia, pp. 167-189. Quaternary Research in Southeast Asia, Volume 18. Leiden: A.A. Balkema.

Spriggs, M. 1989. The dating of the Island Southeast Asian Neolithic: An attempt at chronometric hygiene and linguistic correlation. Antiquity 63(240):587-613. doi.org/10.1017/S0003598X00076560 (accessed 5 June 2018). 
Supriatna, J. 2008. Macaca ochreata. The IUCN Red List of Threatened Species 2008: e.T12557A3357511. doi.org/10.2305/IUCN.UK.2008.RLTS.T12557A3357511.en (accessed 27 October 2018).

Supriatna, J. and M. Richardson. 2008. Macaca tonkeana. The IUCN Red List of Threatened Species 2008: e.T12563A3359793. doi.org/10.2305/IUCN.UK.2008.RLTS.T12563A3359793.en (accessed 27 October 2018).

Tasirin, J., V. Dinets, E. Meijaard, J. Brodie, V. Nijman, T.A.C. Loffeld, H. Hilser, C. Shepherd, A.S. Seymour and J.W. Duckworth. 2015. Macrogalidia musschenbroekii. The IUCN Red List of Threatened Species 2015: e.T12592A45198901. doi.org/10.2305/IUCN.UK.2015-4.RLTS.T12592A45198901.en (accessed 27 October 2018).

van den Bergh, G.D., H.J. Meijer, R. Due Awe, M.J. Morwood, K. Szabo, L.W. van den Hoek Ostende, T. Sutikna, E.W. Saptomo, P.J. Piper and K.M. Dobney. 2009. The Liang Bua faunal remains: a 95k. yr. sequence from Flores, East Indonesia. Journal of Human Evolution 57(5):527-537. doi.org/10.1016/j. jhevol.2008.08.015 (accessed 5 June 2018).

\section{Appendix A}

Table A9.1: Summary of geoarchaeological analyses of sediments from Gua Mo'o hono.

\begin{tabular}{|c|c|c|c|c|c|c|}
\hline $\begin{array}{l}\text { Sample ID } \\
\text { (metres) }\end{array}$ & Average $\mathrm{pH}$ & Mean EC & $\begin{array}{l}\text { LOI percent organic } \\
\text { material average }\end{array}$ & $\begin{array}{l}\text { LOI percent } \\
\text { carbonate content } \\
\text { average }\end{array}$ & $\begin{array}{l}\text { Average } \\
\text { Magnetic } \\
\text { Susceptibility }\end{array}$ & $\begin{array}{l}\text { Munsell colour } \\
\text { (Dry) }\end{array}$ \\
\hline 0.05 & 7.53 & 973.67 & 9.67 & 7.6 & 957.97 & Dark brown \\
\hline 0.1 & 7 & 869 & 7.71 & 8.89 & 848.87 & Dark brown \\
\hline 0.15 & 7.73 & 1135 & 8.36 & 7.35 & 862.65 & Dark brown \\
\hline 0.2 & 7.1 & 980.33 & 8.16 & 9.49 & 1175.74 & Dark brown \\
\hline 0.25 & 7.6 & 1009.33 & 5.51 & 11.8 & 1546.51 & Brown/dark brown \\
\hline 0.3 & 7.4 & 669.33 & 4.43 & 15.36 & 4211.98 & Pinkish-grey \\
\hline 0.34 & 7.73 & 468 & 4.49 & 8.96 & 931.06 & Brown \\
\hline 0.4 & 7.63 & 413.33 & 6.66 & 12.73 & 1682.88 & Brown/dark brown \\
\hline 0.43 & 8.03 & 413 & 3.75 & 18.76 & 2322.91 & Pinkish-grey \\
\hline 0.5 & 7.8 & 283.33 & 4.74 & 16.7 & 1563.01 & Brown \\
\hline 0.54 & 8.23 & 323 & 3.3 & 21.41 & 1949.46 & Pinkish-grey \\
\hline 0.6 & 7.8 & 281.33 & 4.32 & 14.37 & 1315.35 & Brown/dark brown \\
\hline 0.65 & 7.93 & 299 & 6.08 & 15.01 & 1413.28 & Dark brown \\
\hline 0.7 & 7.57 & 289.67 & 5.4 & 10.43 & 1484.89 & Strong brown \\
\hline 0.75 & 8.07 & 281 & 5.01 & 9.7 & 1733 & Brown \\
\hline 0.8 & 7.6 & 276.33 & 7.21 & 11.84 & 2149.98 & Brown \\
\hline 0.85 & 8 & 278.33 & 6.22 & 12.3 & 1842.04 & Brown/dark brown \\
\hline 0.9 & 7 & 276.33 & 6.41 & 13.03 & 1863.44 & Strong brown \\
\hline 0.95 & 8.2 & 287.33 & 6.52 & 12.51 & 1766.66 & Brown/dark brown \\
\hline 1 & 7.97 & 280.33 & 6.74 & 15.22 & 1957.29 & Brown/dark brown \\
\hline 1.05 & 7.97 & 275.67 & 5.66 & 16.78 & 1887.91 & Dark brown \\
\hline 1.1 & 7.33 & 350 & 6.42 & 12.32 & 2463.29 & Brown \\
\hline 1.15 & 8.03 & 281.67 & 6.62 & 11.78 & 2001.88 & Strong brown \\
\hline 1.2 & 7.97 & 266.5 & 7.8 & 13.15 & 2245.07 & Brown \\
\hline 1.25 & 7.9 & 312 & 6.23 & 15.13 & 2620.18 & Brown/dark brown \\
\hline 1.3 & 7.33 & 301.67 & 6.78 & 13.99 & 2706.36 & Brown/dark brown \\
\hline 1.4 & 7.8 & 329.67 & 7.03 & 12.42 & 2167.7 & Dark brown \\
\hline 1.45 & 6.93 & 312 & 7.38 & 13.98 & 2342.5 & Brown/dark brown \\
\hline 1.5 & 7.67 & 404.33 & 7.17 & 11.97 & 1725.56 & Dark brown \\
\hline
\end{tabular}




\begin{tabular}{|c|c|c|c|c|c|c|}
\hline $\begin{array}{l}\text { Sample ID } \\
\text { (metres) }\end{array}$ & Average $\mathrm{pH}$ & Mean EC & $\begin{array}{l}\text { Lol percent organic } \\
\text { material average }\end{array}$ & $\begin{array}{l}\text { LOI percent } \\
\text { carbonate content } \\
\text { average }\end{array}$ & $\begin{array}{l}\text { Average } \\
\text { Magnetic } \\
\text { Susceptibility }\end{array}$ & $\begin{array}{l}\text { Munsell colour } \\
\text { (Dry) }\end{array}$ \\
\hline 1.55 & 7.03 & 367 & 6.47 & 11.39 & 2204.35 & Dark brown \\
\hline 1.6 & 7.87 & 339.67 & 7.6 & 11.31 & 2559.82 & Dark brown \\
\hline 1.65 & 7.47 & 311.67 & 7.55 & 13.3 & 2063.82 & Brown \\
\hline 1.7 & 7.73 & 427 & 8.08 & 10.7 & 2182.47 & Dark brown \\
\hline 1.75 & 7 & 411.33 & 7.14 & 12.37 & 1877.19 & Dark brown \\
\hline 1.8 & 7.6 & 582.67 & 7.21 & 11.48 & 2601.33 & Strong brown \\
\hline 1.85 & 7.27 & 391 & 7.4 & 12.2 & 2404.85 & Strong brown \\
\hline 1.9 & 7.47 & 449.67 & 8.31 & 10.93 & 2129.32 & Brown/dark brown \\
\hline 1.95 & 6.77 & 532.67 & 7.63 & 11.26 & 2136.92 & Strong brown \\
\hline 2 & 7.4 & 501.33 & 7.31 & 13.81 & 2453.27 & Brown/dark brown \\
\hline 2.05 & 7.1 & 393.67 & 7.43 & 10.85 & 1905.35 & Brown \\
\hline 2.1 & 7.33 & 439.67 & 7.68 & 12.7 & 2196.72 & Strong brown \\
\hline 2.15 & 6.83 & 398.33 & 7.28 & 11.52 & 2144.4 & Strong brown \\
\hline 2.2 & 7.8 & 296.33 & 5.82 & 12.68 & 2383.74 & Strong brown \\
\hline 2.3 & 6.9 & 308.33 & 6.06 & 13.96 & 2441.48 & Brown/dark brown \\
\hline 2.35 & 7.53 & 260.33 & 5.99 & 3.82 & 682.31 & Strong brown \\
\hline 2.4 & 7.03 & 167.33 & 5.84 & 3.64 & 375.62 & Strong brown \\
\hline 2.45 & 7.53 & 242.33 & 5.5 & 3.16 & 498.6 & Brown \\
\hline 2.5 & 7.03 & 316.33 & 4.06 & 3.52 & 286.76 & Strong brown \\
\hline
\end{tabular}

Note: $\mathrm{EC}=$ electrical conductivity; LOI = loss on ignition.

Source: Ben Marwick's laboratory data.

\section{Appendix B}

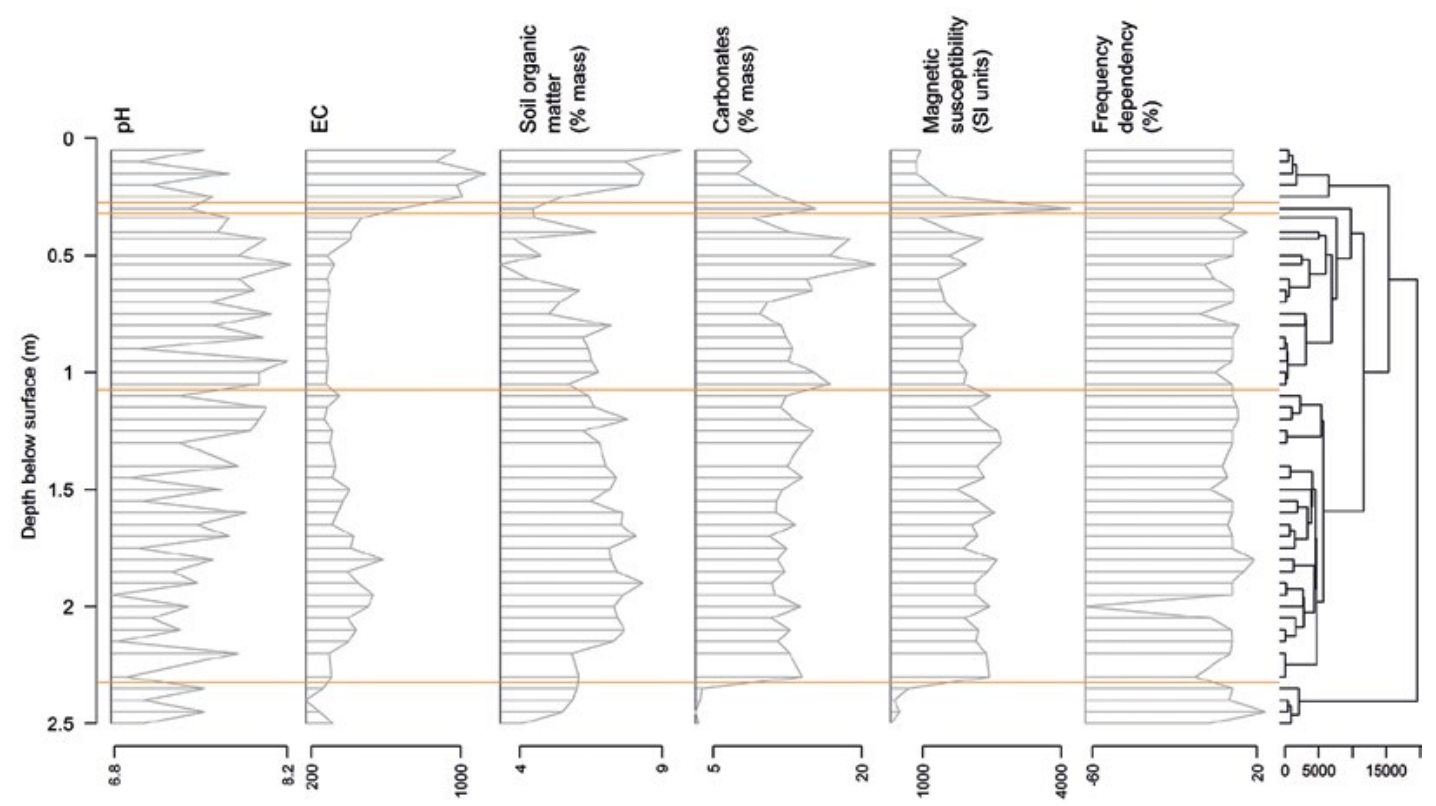

Figure B9.1: Stratigraphic plot of geoarchaeological data from Gua Mo'o hono.

Source: Ben Marwick (based on laboratory observations by archaeology students Ramona Steele and Cheyenne Galindo). 
This text is taken from The Archaeology of Sulawesi: Current Research on the Pleistocene to the Historic Period, edited by Sue O'Connor, David Bulbeck and Juliet Meyer, published 2018 by ANU Press, The Australian National University, Canberra, Australia.

doi.org/10.22459/TA48.11.2018.09 